Working Paper/Document de travail 2012-25

\title{
Does the Buck Stop Here? A Comparison of Withdrawals from Money Market Mutual Funds with Floating and Constant Share Prices
}

by Jonathan Witmer 
Bank of Canada Working Paper 2012-25

August 2012

\title{
Does the Buck Stop Here? A Comparison of Withdrawals from Money Market Mutual Funds with Floating and Constant Share Prices
}

\author{
by \\ Jonathan Witmer \\ Financial Markets Department \\ Bank of Canada \\ Ottawa, Ontario, Canada K1A 0G9 \\ jwitmer@bankofcanada.ca
}

Bank of Canada working papers are theoretical or empirical works-in-progress on subjects in economics and finance. The views expressed in this paper are those of the author. No responsibility for them should be attributed to the Bank of Canada. 


\section{Acknowledgements}

I thank Henrik Andersen, Jean-Sebastien Fontaine, Sermin Gungor, Scott Hendry, Jesus Sierra Jimenez, Stéphane Lavoie, Iwan Meier and seminar participants at the Bank of Canada - Bank of Spain Workshop on International Financial Markets and the GdRE Annual Symposium on Money Banking and Finance for their helpful comments. All remaining errors are my own. 


\begin{abstract}
Recent reform proposals call for an elimination of the constant net asset value (NAV) or "buck" in money market mutual funds to reduce the occurrence of runs. Outside the United States, there are several countries that have money market mutual funds with and without constant NAVs. Using daily data on individual fund flows from these countries, this paper evaluates whether the reliance on a constant NAV is associated with a higher frequency of sustained fund outflows. Preliminary evidence suggests that funds with a constant NAV are more likely to experience sustained outflows, even after controlling for country fixed effects and other factors. Moreover, these sustained outflows in constant NAV money market funds were more acute during the period of the run on the Reserve Primary fund, and were subdued after the U.S. Treasury guarantee program for money market funds was put in place. Consistent with the theory that constant NAV funds receive additional implicit support from fund sponsors, fund liquidations are less prevalent in funds with a constant NAV following periods of larger outflows.
\end{abstract}

JEL classification: F30, G01, G18, G20

Bank classification: Financial markets; Financial stability; Market structure and pricing

\title{
Résumé
}

En vue de réduire le risque de ruée, des propositions de réforme récentes appellent à l'interdiction des fonds communs de placement monétaires à valeur liquidative (VL) constante. Dans plusieurs pays en dehors des États-Unis, les fonds monétaires à VL variable et constante coexistent. À partir de données quotidiennes relatives aux flux financiers issus des fonds de ces pays, l'auteur évalue si le modèle à VL stable est associé à des sorties prolongées de capitaux plus fréquentes. Les résultats préliminaires semblent confirmer que les fonds à VL constante sont plus susceptibles de connaître des sorties prolongées de capitaux, même après prise en compte des effets fixes de pays et d'autres facteurs. En outre, les fuites ont été plus importantes lorsque le fonds Reserve Primary a subi une hémorragie de capitaux, et elles sont tombées après la mise en place par le Trésor américain d'un programme de garantie des fonds monétaires. En accord avec l'idée que les fonds à VL stable reçoivent de leurs promoteurs un soutien implicite supplémentaire, l'auteur constate que les fonds de cette catégorie enregistrent moins de liquidations après des sorties importantes de capitaux.

Classification JEL : F30, G01, G18, G20

Classification de la Banque : Marchés financiers; Stabilité financière; Structure de marché et fixation des prix 


\section{Introduction}

In the United States, money market mutual funds maintain a constant share price, also known as a constant Net Asset Value (NAV), of \$1 per share. As such, a share in a money market mutual fund is similar to a deposit contract since the shareholder is effectively guaranteed the return of her initial investment upon withdrawal of her money from the fund. Unlike a deposit contract, there is no deposit insurance for money market mutual funds, so the lack of such insurance may make them susceptible to a bank run (Diamond and Dybvig, 1983). Indeed, such a run did occur on September $16^{\text {th }} 2008$, when the Primary Reserve fund "broke the buck" as its share price was reduced below $\$ 1$ to $\$ 0.97$. This was followed by massive redemptions in other money market mutual funds and the U.S. Treasury introduced a temporary guarantee program for money market mutual funds to prevent a market-wide run from occurring (FINRA, 2010). This was complemented by the Federal Reserve's asset-backed commercial paper money market mutual fund liquidity facility, which provided liquidity to money market funds that needed to satisfy an influx of redemptions (Duygan-Bump et al, 2012).

In the aftermath of this event, there have been several proposals to reform the structure of the money market mutual fund industry, as part of a broader set of proposals to reform shadow banking (Financial Stability Board, 2010). One of the primary proposals is to abandon the constant share price of $\$ 1$ per share in favour of a floating share price. ${ }^{1}$ In this case, if the intrinsic value of the fund falls in value, this will be reflected in the share price, and the redeeming shareholders should have less incentive to run for the exits. Therefore, it is generally believed that moving away from a constant share price structure will reduce the risk of a run. Nonetheless, there may still be a risk of runs in floating share price money market mutual funds as well. Jenk and Wedow (2010), for example, find evidence of runs from illiquid money market mutual funds in Germany, where mutual funds do not have a constant share price structure. There is also some anecdotal evidence that suggests a floating NAV does little to reduce the occurrence of runs on money market mutual funds (e.g., Investment Company Institute, 2011; HSBC, 2011; Bengtsson, 2010).

The focus of this paper is to empirically examine whether floating NAVs provide a benefit in reducing run-like behaviour. To do so, I examine the flow and withdrawal behaviour of money market mutual funds in the United States and Europe. Unlike the United States, many European countries have money market mutual funds with and without constant NAVs and hence provide an opportunity to

\footnotetext{
${ }^{1}$ The Technical Committee of the International Organization of Securities Commissions has examined several proposals in a recent consultation report (IOSCO, 2012). Other proposals include calls for money market mutual funds to pay insurance fees (like deposit insurance) and to maintain a minimum buffer (similar to a minimum capital ratio). Following the crisis, several countries have implemented increased disclosure and stricter restrictions on the portfolios of money market mutual funds (See Section 2 for a discussion of these requirements).
} 
examine how flow behaviour is different under these structures. This paper fills a void in the academic literature since it is essentially the first to examine the pricing structure of money market mutual funds. The only prior paper, to the best of my knowledge, is Lyon (1984), which investigates the effect of the SEC allowing money market mutual funds to use amortized cost accounting (i.e., a CNAV structure) in the United States in the late 1970s. This prior paper is concerned with flow behaviour and evidence of arbitrage in this structure, and not directly on the link between the pricing structure and the incidence of runs. Nonetheless, the paper is similar to this one in that they both provide evidence of a link between the constant share price and flow behaviour in money market mutual funds.

This paper is the first to examine the usage of a constant NAV structure across countries. It is well known that money market funds in some countries, such as the United States, employ a constant NAV structure. It is less well known to what extent other countries use a different structure. The main difference between floating NAV and constant NAV money market funds is the use of amortized cost accounting. ${ }^{2}$ Floating NAV money market mutual funds measure the value of their positions using fair value or market prices. For constant NAV money market funds, the value is recorded as the initial cost, plus the straight line amortization of the position's premium or discount at the time of purchase through to the position's maturity date. This paper shows that many European countries have a mixture of both fund types.

This paper also contributes to the broader literature that examines the relation between stale share prices, illiquid fund holdings, and fund flows in equity and bond mutual funds. Arbitrageurs can take advantage of stale prices in illiquid mutual funds at the expense of the remaining shareholders. These apparent arbitrage opportunities induce a change in flows in these mutual funds. The paper by Lyon (1984) finds this arbitrage activity dilutes other shareholders in money market funds by an estimated 10 bps per year. This dilution is even larger in international equity mutual funds, where dilution can be upwards of 1\% per year (e.g., Greene and Hodges, 2002; Zitzewitz, 2003). Chen, Goldstein and Jiang (2010) use a global games approach to model payoff complementarities and financial fragility in mutual funds. In their model, investor withdrawals impose a negative externality on the remaining fund shareholders, especially in those funds that may need to liquidate illiquid asset holdings (Edelen, 1999). This amplifies the effect of fund performance on flows in illiquid funds, since investors may redeem their shares on the self-fulfilling belief that other investors also are redeeming shares. They confirm their model empirically in the flow-performance relation in equity mutual funds.

\footnotetext{
${ }^{2}$ A constant NAV is a function of two components: amortized cost accounting and penny rounding. Some constant NAV funds distribute income (which I will refer to as stable NAV funds) so that their share price always remains constant. I use a broader definition of constant NAV mutual funds to include those that accumulate income, so that the share increases.
} 
Money market mutual funds with a constant NAV are similar to funds holding illiquid assets or funds with a stale share price: in these situations, investors may be able to trade at a price that does not properly reflect the price that would be received from liquidating the underlying assets, thus imposing a negative externality on the remaining shareholders. As such, it may create additional financial fragility in money market mutual funds. A floating NAV may overcome this problem; however, it critically depends on the extent to which the floating NAV correctly reflects the costs of liquidating the underlying holdings during a period of heavy redemptions. Thus, it is an empirical question as to whether there is much of a difference between floating and constant NAV mutual funds in preventing runs.

Using data from international mutual funds, this paper finds that constant share price funds are more susceptible to periods of prolonged outflows, after controlling for variables such as size and the fund investor type (e.g., institutional vs. retail) as well as LIBOR-OIS spreads, that may have an impact on flow behaviour. The 3-month LIBOR-OIS spread is used as a proxy for the performance of the underlying holdings (since a large portion of money funds hold commercial paper, including from financial issuers). When LIBOR-OIS spreads increase, these funds also experience more periods of prolonged outflows. Hence, the results for money market mutual funds provide evidence that is consistent with arbitrage and stale prices in mutual funds (Lyon, 1984; Greene and Hodges, 2002; Zitzewitz, 2003). During the first part of September 2008 when there was a run on the Reserve Primary Fund, constant NAV money market funds experienced more outflows than did floating NAV money market funds. Further, after the U.S. Treasury implemented its guarantee program for money market funds, constant NAV U.S.-domiciled U.S. dollar funds performed much better and sustained a decrease in prolonged outflows during the guarantee period, relative to non-U.S. domiciled U.S. dollar funds.

Fund sponsors provide an implicit guarantee that should mitigate the incidence of runs in constant NAV money market mutual funds. Funds with sponsors in a better financial condition are more likely to benefit from such a guarantee. Kacperczyk and Schnabl (2012) do not find any impact of fund sponsor characteristics on the flow-performance relation and suggest that this is due to a lack of risk adjustment on the part of investors. This paper complements this work by testing for the presence of such support in both floating and constant NAV money market funds and by using a different measure of fund net outflows. There should be less of a need for such sponsor support in floating NAV funds because by definition there is no guarantee that these funds maintain their value. In this paper I find weak evidence for a different relation between outflows and sponsor CDS spreads in constant NAV and variable NAV funds. 
Constant NAV funds are, however, less likely to be liquidated when the fund is experiencing heavier outflows, which may be a result of the presence of an implicit guarantee. That is, fund sponsors may be less likely to support floating NAV funds to prevent them from being liquidated. As expected, funds that experience more periods of sustained outflows are more likely to be liquidated. All in all, this suggests a relation between a fund's use of the constant price structure, implicit fund sponsor guarantees, and ultimately the fund's survival.

Although this paper documents an increased frequency of prolonged outflows in constant NAV mutual funds, it does not necessarily imply that this is the preferred structure since it is not performing a holistic evaluation of all the benefits and disadvantages of the two structures. Importantly, there are several advantages of constant NAV money market funds that are not considered in this paper. First, the CNAV structure may reduce tax, bookkeeping and operational costs for investors. Second, because some investors can only invest in cash pools with a stable NAV, the industry argues that a switch to a floating NAV could result in extra risk to the financial system if these funds are directed towards less regulated vehicles outside of the current regulatory framework (e.g., Investment Company Institute, 2012).

The rest of the paper is organized as follows. In the next section, I provide an institutional background on the regulation of money market mutual funds in Europe and the United States, focusing on the pricing and valuation aspects of the regulations. Section 3 develops the main testable hypotheses. In Section 4, I describe the data and report summary statistics. Section 5 describes the empirical methodology and presents empirical findings. In Section 6, I discuss robustness checks and provide some concluding remarks in Section 7.

\section{Institutional background on constant NAV}

\subsection{United States}

With the exception of money market mutual funds, all U.S. mutual funds must report a floating net asset value that represents the market value or fair value of the securities held in its portfolio. The Securities and Exchange Commission (SEC) officially exempted money market funds from this requirement in 1983, when it allowed for the use of amortized cost accounting and the penny rounding method (SEC, 1983). ${ }^{3}$ These two components allow a money market fund to maintain a constant net asset value. Under the penny rounding method, a fund company can report the fund's share price by rounding the net asset value per share to the nearest cent, assuming a share price of $\$ 1$. Hence, a fund's share price can be reported as $\$ 1$ if the net asset value is between $\$ 0.995$ and $\$ 1.005$. Under amortized cost

\footnotetext{
${ }^{3}$ Prior to this, the SEC had granted individual orders of exemption to money market funds, which allowed those funds to use amortized cost accounting and the penny rounding method (SEC, 1983).
} 
accounting, a fund can value its holdings at their acquisition cost, adjusted to linearly amortize the premium or discount until the holding's maturity. The fair value or market value may deviate from this amortized cost accounting valuation, but at maturity the two valuation methods should coincide, provided there is no default by the security's issuer.

Along with this change, the SEC added several risk-reducing conditions to "...ensure that any money market fund that adopts one of the above procedures in an effort to maintain a stable price per share will be able to maintain that stable price." In rule 2a-7, the SEC placed restrictions on the portfolio's holdings, designed to minimize the funds' exposure to credit risk and interest rate risk. All the portfolio investments were to have a remaining maturity of one year or less, and the dollar-weighted portfolio maturity could not exceed 120 days (this was later reduced to 90 days in 1991). ${ }^{4}$ Illiquid securities could not represent more than ten percent of the fund's assets. Further, the portfolio needed to consist of securities that a major rating company determined as "high quality", along with a requirement that the board determine that the security "...presents minimal credit risk to the fund."

On top of these restrictions, the fund's board is obliged to assess the fairness of the fund's valuation and pricing methodology and to take steps such that this methodology fairly reflects the fund's value per share. In particular, the board must monitor the deviation between the fund's amortized costbased price and the fund's value based on market prices that the fund would receive based on the sale of the security. Thus, Fisch and Roiter (2011) argue that U.S. money market funds are really only CNAV funds under certain circumstances. However, there is the possibility that a board may not adjust its price in a timely manner, and there could also be incentives against doing so given the stigma associated with "breaking the buck."

After the crisis, the SEC amended rule 2a-7 to improve the resiliency of money market mutual funds. These amendments included tighter restrictions on the credit quality, maturity, and liquidity of portfolio holdings for money market funds. The maximum dollar-weighted average maturity was reduced to 60 days, and a maximum dollar-weighted average life to maturity was introduced and set at 120 days. $^{5}$ As for the liquidity requirements, a minimum of ten percent of a fund's portfolios must be invested in "Daily Liquid Assets" and a minimum of thirty percent must be invested in "Weekly Liquid Assets". The amended rule 2a-7 also requires monthly website disclosure of portfolio holdings, including information

\footnotetext{
${ }^{4}$ Prior to the crisis, the SEC made significant amendments to rule 2a-7 in 1986, 1991, and 1996. Refer to Money Markets Working Group (2009), Appendix E for a detailed history of the rule 2a-7 amendments.

${ }^{5}$ Funds can use the next interest rate reset date for floating rate notes as its maturity when calculating dollar-weighted average maturity, but not when calculating dollar-weighted average life to maturity.
} 
on each portfolio security's amortized cost value. In addition, funds must report the market value of each portfolio security to the SEC, which becomes publicly available with a 60 day lag.

\subsection{Europe}

In Europe, most money market funds (and other mutual funds) are structured as Undertakings for Collective Investment in Transferrable Securities (UCITS). The UCITS Directive outlines rules concerning the eligible assets for mutual funds. Under this directive, funds are allowed to use amortized cost accounting for some money market instruments, provided the fund follows the guidelines set out by the Committee of European Securities Regulators (CESR, 2007). The fund must ensure that there is not a material discrepancy between the value of the money market instrument and its amortized cost valuation. Moreover, these CESR guidelines include two principles that state where amortized cost accounting may be used. It could be applied to money market instruments with a residual maturity of less than three months and with no specific sensitivity to market parameters, including credit risk. Alternatively, funds investing solely in high-quality instruments with residual maturities less than or equal to 397 days and with a weighted average portfolio maturity of 60 days may use the amortized cost method. While these rules provide for the use of amortized cost accounting, some national regulators, such as those in France and Ireland, have imposed more stringent rules (International Organization of Securities Commissions, 2012).

A notable difference between European and U.S. funds is in the distribution of income. In the United States, most funds distribute income to the unitholders, so that the share price maintains a stable value. In Europe, many funds accumulate income, such that income earned by the fund results in an increase in the fund's net asset value. There are also different share classes within some funds that differ in this regard. Both types of funds may potentially be using amortized cost accounting. Funds state in their annual report their valuation methodology and in many cases the fund often states that the fund uses amortized cost accounting except in cases where the market value of the position changes, so it is difficult to discern the extent of the use of amortized cost accounting from annual reports.

The International Money Market Fund Association (IMMFA) is a European self-regulatory trade association that sets a code of practice for its members' triple-A rated CNAV money market mutual funds (IMMFA, 2011). The code of conduct is similar to the U.S. regulations in that it places restrictions on portfolio credit quality and maturity. IMMFA funds and securities are priced using the amortized cost methodology, but deviations between market value and amortized cost value must be monitored at a weekly frequency or greater. Along with this monitoring, there is an escalation policy that must be followed once deviations at the portfolio level exceed ten basis points. The code of conduct limits the 
weighted average portfolio maturity to 60 days and sets minimum credit ratings on the securities in the fund's portfolio. After the crisis, the IMMFA amended the code to tighten the risk-limiting conditions including adding diversification limits, a maximum final legal maturity of 397 days, and requirements on the credit ratings and minimum criteria on credit ratings. As well, the code requires monthly disclosure of all portfolio holdings.

\section{Hypothesis Development}

Financial fragility exists in mutual funds. For example, Chen, Goldstein, and Jiang (2010) develop a model whereby mutual funds holding illiquid assets experience more outflows following a period of poor performance than do funds holding liquid assets. This is the result of strategic complementarities in funds with illiquid assets: withdrawing shareholders impose a negative externality on remaining shareholders. Specifically, investor redemptions decrease future fund returns, since the fund incurs direct and indirect costs to readjust its underlying portfolio as a result of these redemptions, and these costs are not incorporated in the price investors receive for their redemptions (Chordia, 1996; Nanda, Narayanan \& Warther, 2000, Edelen, 1999). Moreover, these costs are likely to be more important in funds that hold illiquid assets. Self-fulfilling beliefs amplify the effect of fund performance on flows in illiquid funds, because investors may redeem their shares on the belief that other investors also are redeeming shares.

Chen, Goldstein and Jiang (2010) find empirical support for their model in the flow-performance relationship in equity mutual funds. A similar relationship also likely exists in money market mutual funds, and would likely be more pronounced in CNAV funds. Like illiquid funds in the model discussed above, CNAV money market funds rely on a share price that does not reflect the true value of the underlying portfolio. In this sense, redemptions in CNAV mutual funds impose a greater externality on remaining investors. This would suggest that CNAV money market mutual funds would be associated with a higher level of outflows and that there should be a greater flow-performance relationship in these outflows. That is, after a period of poor performance, CNAV mutual funds would be more likely to experience outflows. Interpreted differently, CNAV mutual funds provide an opportunity for arbitrageurs to trade on the misevaluations of CNAV mutual funds relative to their mark-to-market value. Lyon (1984) finds evidence for this arbitrage and estimates that this activity results in losses of about 10 bps per share to the remaining shareholders in the fund. ${ }^{6}$

This leads to the first hypothesis:

\footnotetext{
${ }^{6}$ This arbitrage activity also occurs in equity and bond mutual funds that have a floating net asset value, mostly because these funds hold illiquid securities whose prices may be stale and hence are not properly reflected in the fund's net asset value. Zitzewitz (2003) estimates that this activity results in a dilution of 56 to 114 basis points in international equity funds.
} 
Hypothesis 1: CNAV mutual funds are more likely to experience episodes of sustained outflows, relative to VNAV mutual funds.

In CNAV money market mutual funds, fund sponsors may provide an implicit guarantee to reduce the likelihood of a self-fulfilling run. Moody's Investor Services reports that 62 CNAV money market funds in Europe and the United States received some form of financial support from their fund sponsor during the 2007-2009 financial crisis. Moreover, sponsors in better financial condition should be more likely to provide such support. During the run on money market funds in 2008, U.S. CNAV funds that had sponsors with wider CDS spreads experienced larger outflows (McCabe, 2010). Thus, if investors rely on these implicit guarantees, fund sponsors in better financial condition should be less likely to experience fund redemptions in their CNAV funds.

Also impacting the analysis is the fact that risk-taking in funds is lower in funds with sponsors with limited financial resources and lower in those funds where there are concerns about negative spillovers to the rest of the fund sponsor's business (Kacperczyk and Schnabl, 2012). So, this risk-taking channel may also result in fewer redemptions in funds with sponsors in worse financial condition and with more reputational concerns, since funds that undertake less risk may be expected, all else equal, to experience fewer redemptions. The empirical analysis attempts to isolate the effect of the implicit guarantee by controlling for fund riskiness.

In VNAV mutual funds, on the other hand, it may be less likely that there is an implicit guarantee by the fund sponsor to maintain the fund's share price at a certain level. Since the price of a VNAV fund fluctuates, investors may be more accustomed to the potential to sustain losses in a VAV fund. If this is the case, there should be a much weaker relation between fund flows and the fund sponsor's financial strength in VNAV money market funds. As far as reputational spillovers are concerned, when a CNAV fund breaks the buck it receives a lot of negative press and therefore may also be more likely to have a negative impact on the sponsor's other business, relative to VNAV funds. Thus, in additional to their financial strength, fund sponsor reputational concerns may also have an impact on sustained outflows:

Hypothesis 2: Sustained outflows in CNAV mutual funds are more sensitive to the fund sponsor's financial condition and fund sponsor reputational concerns, relative to sustained outflows in VNAV mutual funds.

Implicit guarantees are also likely to effect the survival of money market mutual funds. If a fund sponsor is likely to step in and provide an implicit guarantee of the CNAV fund's share price should the fund underperform, then the fund's chances of survival should also increase as a result of this implicit 
guarantee. On the other hand, the first hypothesis would suggest that CNAV money market funds are more prone to experience episodes of sustained outflows, which could ultimately result in a fund's liquidation. To examine the differences between CNAV and VNAV funds, this paper examines how liquidation differs following periods of heavy redemptions. If the fund sponsor does not provide an implicit guarantee (such as in the case of a VNAV mutual fund), the fund may be liquidated following a period of heavy redemptions.

Hypothesis 3: VNAV mutual funds are more likely to be liquidated following periods of heavy outflows, relative to CNAV mutual funds.

\section{Sample and Descriptive Statistics}

\subsection{Sample}

Morningstar is the source of the money market mutual fund data in this paper. I begin by selecting all money market mutual funds domiciled in the United States and Europe. Funds that are not denominated in Euros or U.S. dollars are removed from the sample. Morningstar provides information at the fund share class level. Funds often have several share classes catering to different clients (e.g., institutional or retail), with different minimum investment criteria, and with different management fees. For all of these share classes, I collect daily information on the net asset value per share, the assets under management at the share class level, as well as the assets under management at the fund level from January 1, 2006 through December 31, 2011. This paper focuses on those funds that report their fund size at a daily frequency. To remove data that is not reported at a daily frequency, I count the number of observations of fund size in every month and remove those observations where the fund does not report the fund size at least 10 times in that month.

Most of the analysis in this paper is performed at the fund level. Therefore, for each fund, I only keep share class information from the largest share class and use this information to classify the funds into different categories. For example, funds can be classified as either institutional funds or retail funds. A fund is classified as institutional if its largest share class is classified as institutional according to Morningstar. This information is available for most, but not all funds. For those funds without a Morningstar Institutional classification, I classify them as institutional if the minimum required investment is greater than $€ 100,000$ or $\$ 100,000$, depending on the fund's currency. As well, if the fund's largest share class is a class of type "I", it is classified as institutional.

Funds focusing on government securities are also excluded from the analysis. Government securities are less information-sensitive than non-government securities and funds holding mostly 
government securities should be less prone to runs than funds holding private sector securities. This was the case in the United States in September 2008, when there was a run from prime money market funds to government money market funds (ICI Factbook, 2008). Funds are classified as a government fund if the fund name contains "Gov", "Sovereign" or "Treasury" and are hence removed. Municipal funds, identified as those with a fund name that contains "Muni", are also removed. Small funds, with an average fund size less than $€ 50$ million or $\$ 50$ million, are also excluded.

Morningstar does not categorize funds as having a constant or a floating NAV. Therefore, I use the following algorithm to determine a fund's NAV structure. If a fund's share price is equal to $\$ 1, € 1$, $\$ 10$, or $€ 10$ throughout the sample period, it is categorized as a constant NAV fund. This is a very strict interpretation of the definition of a constant NAV mutual fund, because it ignores funds that accumulate income instead of distribute income. One of the main differences between constant and floating NAV mutual funds is the extent to which they use amortized cost accounting. A broader definition of a CNAV fund that attempts to capture the use of amortized cost accounting is examined in the robustness section.

At the end of the third quarter in 2011, Money market funds in France, Luxembourg, Ireland, and the United States had assets under management of \$490 billion, \$376 billion, \$475 billion, and \$2.6 trillion, respectively (European Fund and Asset Management Association, 2011). As Table 1 shows, the sample examined in this paper covers a substantial portion of these markets. Our sample market size is smaller as a result of the focus on non-government funds, on funds denominated in Euros and U.S. dollars (which eliminates Sterling funds in Ireland, for example), and funds that report their fund size at a daily frequency. From Table 1, it is also apparent that VNAV mutual funds are, on average, smaller than CNAV mutual funds, with the average CNAV fund size being a multiple of the average VNAV fund size. Part of this is the result of a skewed distribution in that the very large money market mutual funds are CNAV funds. The table also categorizes VNAV funds in terms of their variability by splitting them into three groups: those that experience no share price declines, those that experience share price declines $5 \%$ of the time or less, and those that experience such a decline more than $5 \%$ of the time. In each of the different subsamples, there is a mix of both low-variability and high variability VNAV funds. While no money market funds in France maintain a stable share price of $€ 1$ or $€ 10$, a significant portion of funds show little variation, based on the absence of a share price decrease over the sample period. Of the 262 French Euro-denominated money market funds that are classified as VNAV mutual funds, $49 \%$ of them have never experienced a decline in their fund share price. This could indicate that these funds may be using amortized cost accounting.

\subsection{Fund outflows}


A concern with CNAV mutual funds is that this structure may be more susceptible to runs. This paper measures run behaviour using information from fund outflows. Specifically, it measures significant periods of fund outflows associated with the CNAV and VNAV structures to determine whether there is any difference in flow behaviour between these two types of money market mutual funds. Several choices could be used as a measure of economically significant fund outflows. For example, these outflows could be measured at a daily, weekly, or even a monthly horizon. Using flow behaviour measured over a single day is problematic for two reasons. First, institutions often deposit cash in money market mutual funds and withdraw this cash a day or a couple of days later (leading to negative autocorrelation in money market fund flows as discussed in Wermers (2011)). A measure at a daily frequency may incorrectly classify this type of flow as a run. Second, a large withdrawal from a fund at a daily frequency may be the result of a single client removing money from the fund, which also should not be classified as a run. A measure at a weekly frequency would address the first concern, but may still be susceptible to the second concern. The measure proposed in this paper looks for evidence of sustained withdrawals, which are less likely to be the result of a single client withdrawing from the fund. I consider a fund to experience a sustained outflow if its outflows are greater than $1 \%$ of its net assets over a consecutive 3 -day period. ${ }^{7}$

Table 2 and Figure 1a display the frequency of these sustained outflows for U.S. dollar CNAV mutual funds domiciled in the United States as well as for European VNAV and CNAV U.S. dollardenominated mutual funds. Sustained outflows occur relatively infrequently, about $1 \%$ of the time for VNAV funds. Showing the appropriateness of this measure, the frequency of runs spiked during September 2008, when there was a run on money market mutual funds in the United States. Interestingly, non-U.S. domiciled CNAV mutual funds experienced a similar pattern, with an even larger increase in sustained outflows in September 2008. The VNAV mutual funds, on the other hand, showed a milder increase in sustained outflows during this period, and throughout pretty much the entire sample period. A similar relation is also evident in Euro denominated funds (Figure 1b). These findings are consistent with the first hypothesis that CNAV mutual funds are more like to experience sustained outflow behaviour. But, there are differences between CNAV and VNAV mutual funds, including differences in the average size of these funds, which may also explain this evidence. This will be investigated in further detail in Section 5 .

\section{Empirical Methodology and Findings}

\subsection{Fund flows and fund share price structure}

\footnotetext{
${ }^{7}$ The robustness of the results to different measures of outflows is examined in the robustness section.
} 
My first hypothesis is interested in the relation between these sustained outflows and whether a fund utilizes a constant or floating share price structure. The following daily random effects panel logit regression is estimated to test the first hypothesis: ${ }^{8}$

$$
\begin{aligned}
\operatorname{Pr}\left[\text { Outflow }_{i t}=1\right] & =\Lambda\left(\alpha+\beta_{1} C N A V+\beta_{2} \text { Institutional }+\beta_{3}\right. \text { Ln (Fund Size) } \\
& +\beta_{4} \text { Crisis }+\beta_{5} \text { CNAV } * \text { Crisis }+\beta_{6} \text { Guarantee }+\beta_{7} C N A V^{*} \text { Guarantee } \\
& +\beta_{8} C N A V^{*} \text { Guarantee } * U S+\beta_{9} \text { Post-Guarantee }+\beta_{10} C N A V^{*} \text { Post-Guarantee } \\
& \left.+\beta_{4} \triangle \text { LIBOR-OIS }+\beta_{5} \text { CNAV } * \text { LIBOR-OIS }+\mathrm{v}_{\mathrm{i}}+\varepsilon_{\mathrm{it}}\right)
\end{aligned}
$$

In this regression, the dependent variable is the measure of sustained outflows: it takes the value of 1 when a fund has experienced three consecutive days of outflows greater than $1 \%$ of assets under management. At all other times, it is set equal to zero. $\Lambda($.$) is the logistic cumulative distribution$ function.

The coefficient of interest in this regression is the $\beta_{1}$ coefficient associated with the CNAV dummy variable (the indicator of whether a fund maintains a constant share price). Under the hypothesis that CNAV mutual funds are more likely to experience these sustained outflows, this $\beta_{1}$ coefficient would be expected to be positive. Also, this model follows a differences-in-differences approach and includes an interaction term between the $C N A V$ dummy variable, with three separate dummy variables representing different time periods. Crisis is a dummy variable that is equal to one from September 1, 2008 through September $30^{\text {th }}, 2008$, and zero otherwise. Guarantee is a dummy variable that is equal to one during the period from September $20^{\text {th }}, 2008$ through September $19^{\text {th }}, 2009$, and zero otherwise. This corresponds to the time when the U.S. Treasury provided a guarantee for U.S. money market mutual funds. Finally, Postguarantee is a dummy variable that is equal to one during the period from September $20^{\text {th }}, 2009$ onwards, and zero otherwise.

The crisis time period corresponds to the time when the Reserve Primary Fund "broke the buck", and there was a sharp decline in assets under management at U.S. prime money market mutual funds. The interactive coefficient, $\beta_{5}$, tests whether the sustained outflows in CNAV funds were different during the period when the Reserve Primary fund broke the buck. If CNAV money market funds are more

\footnotetext{
${ }^{8}$ Since the dependent variable in this regression is a measure of three-day outflows, the above regression results in overlapping time periods, which could have an impact on the standard error estimates in the regression. To address this concern, the regression is also run using data sampled at three-day intervals to avoid the use of overlapping periods. The regression results using this method are similar. Further, in the robustness section, the results are re-estimated using outflows based on a measure of one-day flows, which would not be subject to the concerns of overlapping periods. Results are also similar using this alternative method.
} 
susceptible to runs, this would be the precise period when we should expect to see a higher preponderance of outflows and hence the $\beta_{5}$ coefficient is expected to be positive.

During the period of the U.S. Treasury guarantee program, U.S. money market fund investors were protected on the downside; therefore, U.S. money market funds should be less likely to experience sustained outflows during this period and the $\beta_{8}$ coefficient in regression (1) should be negative. Note that this coefficient measures the impact on U.S.-domiciled CNAV money market funds relative to non-U.S.domiciled CNAV funds, whereas the $\beta_{7}$ coefficient measures the impact on non-U.S.-domiciled money market mutual funds. The guarantee program only applied to U.S. money market mutual funds, given that there was no similar guarantee in Europe.

During the post-guarantee period, money market fund regulations were tightened in several jurisdictions (see Section 2). If these restrictions reduced the riskiness and increased the liquidity of CNAV money market mutual funds more so than VNAV funds, there should be less of a difference in outflow behaviour between CNAV money market funds and VNAV money market funds, as measured by the $\beta_{10}$ coefficient.

Of course, several other factors could contribute to sustained outflows so other variables are also included in this regression. Institutional shareholders are more likely to exhibit different behaviour regarding fund outflows. Wermers (2011), for example, demonstrates that runs on money market mutual funds in the United States were much more prevalent in institutional money market mutual funds. Perhaps this is attributable to a greater level of sophistication among institutional investors combined with better information relative to retail investors (e.g., due to their economies of scale, they have access to information on fund flows and fund holdings from data vendors). Along the same reasoning, fund size is also included as a control variable.

The change in LIBOR-OIS spreads is used to measure sustained outflows related to changes in the performance of the portfolio underlying the mutual funds. Ideally, the performance should be measured using the returns of the individual assets held by the funds, but there is an absence of good data on the performance of the individual assets held by these funds. ${ }^{9}$ Since most funds hold assets such as commercial paper that are sensitive to changes in short term funding conditions, this paper uses bank credit spreads as a measure of these funding conditions. Since CNAV fund outflows may have a different sensitivity to a change in the LIBOR-OIS spread, the CNAV*LIBOR-OIS interaction term is also included.

\footnotetext{
${ }^{9}$ The funds provide data on fund returns, but for CNAV funds these are based on amortized cost accounting and may not be representative of the returns on the fund's holdings.
} 
Of course, these spreads will be a better measure of portfolio performance for a fund that holds all commercial paper, relative to one that holds all government debt. Hence, this measure would be confounded if VNAV funds, on average, held a different proportion of government securities relative to CNAV funds. The regressions account for this by examining firms with different risk profiles. The change in LIBOR-OIS over the previous three-day period is used as the measure of funding conditions for U.S. dollar funds, while the three-day change in EURIBOR-OIS is used as the measure for Eurodenominated funds. A three-day period is chosen to correspond to the measure of sustained outflows over a three-day period.

The results from this regression are presented in Table 3. For both Euro and U.S. dollar funds, the $\beta_{1}$ coefficient associated with the CNAV dummy variable is positive and is statistically significant for U.S. dollar funds, suggesting a higher likelihood of sustained outflows for CNAV funds relative to VNAV funds during the pre-crisis period. The coefficient on the interaction CNAV*Crisis is positive and statistically significant in both Euro and U.S. dollar funds. During the period of the Treasury guarantee, there was still a heightened level of sustained outflows for VNAV funds, demonstrated by the positive, statistically significant coefficient on Guarantee Date. However, U.S.-domiciled CNAV funds were relatively less likely to experience sustained outflows. The statistically significant, negative coefficient on $U S * C N A V *$ Guarantee highlights the fact that U.S.-domiciled funds were less likely than other U.S. dollar CNAV funds to experience outflows during this period, likely a result of the U.S. Treasury guarantee program. Finally, in the post-guarantee period, there is an elevated occurrence of sustained outflows in CNAV mutual funds, since the coefficient on the CNAV* Post Guarantee interaction term is positive and statistically significant.

The second and third columns examine Low Return and High Return funds, respectively. This subsample analysis attempts to address the concern that some of the results could be due to differences in the relative riskiness of CNAV and VNAV funds. ${ }^{10}$ Low Return funds are defined as those funds whose return over the period from July 2008 through August 2008 were below the return of the median fund with the same currency and share price structure (e.g., the median return for U.S. dollar CNAV funds). Likewise, High Return funds are defined as those funds with a return above the median fund return over the same period. Returns are being used as a measure of fund riskiness, since funds with higher returns are likely holding riskier assets such as commercial paper and asset-backed commercial paper that enable them to generate higher returns. The period of July to August 2008 was chosen to measure the riskiness of

\footnotetext{
${ }^{10}$ Similarly, McCabe (2010) uses gross yields as a proxy for risk and finds that outflows were larger during the crisis for those funds that had higher gross yields in the year prior to the crisis. The volatility of returns could also be used as a measure of fund riskiness, but funds that used amortized cost accounting will have reported returns that are much less volatile than their actual holdings.
} 
the fund right before the crisis. ${ }^{11}$ A short period was chosen since the maturity of money market fund portfolios is also short by regulation. In Table 3, the Low Return U.S. dollar funds and the High Return Euro-denominated funds still have a positive, statistically significant $\beta_{1}$ coefficient. Even more striking is the result that there is a statistically significant, negative coefficient on $U S{ }^{*} C N A V^{*}$ Guarantee for High Return funds only, illustrating that the riskier U.S. CNAV funds experienced a lower likelihood of sustained outflows when the U.S. Treasury guarantee was in effect, relative to the riskier non-U.S. CNAV funds. The riskier, High Return CNAV funds would have been more likely to experience sustained outflows in the absence of the guarantee (i.e., the sum of the coefficients on Guarantee Date and CNAV* Guarantee date is larger for High Return funds). Hence the guarantee should have a larger impact on these funds.

\subsection{Fund flows, fund share price structure, and sponsor financial condition}

If there is an implicit guarantee in CNAV money market mutual funds then, according to Hypothesis 2, a CNAV fund should experience more sustained outflows if there is a lower likelihood of fund sponsor support. The presence of CDS data on the fund sponsor could be one measure of the likelihood of support. Large firms and firms that are part of commercial banks or insurance companies are more likely to have quoted CDS prices, whereas most small firms and standalone investment management companies do not have quoted CDS prices. In a similar vein, Kacperczyk and Schnabl (2012) use the level of the CDS spread as a measure of sponsor strength. So, in addition to the presence of CDS data, an increase in CDS spreads should have a bigger impact on the likelihood of sustained outflows in CNAV funds vis-à-vis VNAV funds. For funds with sponsors that do not have CDS data, this change is set equal to zero. ${ }^{12}$

$$
\begin{aligned}
\operatorname{Pr}\left[\text { Outflow }_{i t}=1\right] & =\Lambda\left(\alpha+\beta_{1} C N A V+\beta_{2} \text { Institutional }+\beta_{3}\right. \text { Ln (Fund Size) } \\
& +\beta_{4} \text { Crisis }+\beta_{5} C N A V^{*} \text { Crisis }+\beta_{6} \text { Guarantee }+\beta_{7} C N A V * \text { Guarantee } \\
& +\beta_{8} C N A V^{*} \text { Guarantee } * \text { US }+\beta_{9} \text { Post-Guarantee }+\beta_{10} C N A V * \text { Post-Guarantee } \\
& +\beta_{11} \text { LLIBOR-OIS }+\beta_{12} C N A V * \Delta L I B O R-O I S+\beta_{13} \text { Sponsor CDS Data } \\
& +\beta_{14} \text { CNAV* Sponsor CDS Data }+\beta_{15} \text { Sponsor CDS Change } \\
& \left.+\beta_{16} \text { CNAV * Sponsor CDS Change }+v_{\mathrm{i}}+\varepsilon_{\mathrm{it}}\right)
\end{aligned}
$$

\footnotetext{
${ }^{11}$ The results in Kazpercyk and Schnabl (2012) suggest that there was an expansion of risk-taking opportunities in money market mutual funds in the year prior to the run on the Reserve Primary fund.

${ }^{12}$ For the fixed effect regressions, funds with sponsors that do not have CDS data are excluded.
} 
Table 4 presents the results. For U.S. dollar funds, there is no relation between the presence of CDS data and the likelihood of sustained outflows for CNAV funds. The $\beta_{13}$ and $\beta_{14}$ coefficients in the above regression are both statistically insignificant. For VNAV funds, I would expect either no relation or a small, negative relation between sponsor financial strength and sustained outflows. However, the opposite is the case: when a fund sponsor's financial condition worsens, VNAV mutual funds are less likely to experience a sustained outflow, as evidenced by the negative, statistically significant coefficient on Sponsor CDS Change.

The coefficient on $C N A V *$ Sponsor CDS Change, on the other hand, is positive and statistically significant. When the fund sponsor's financial condition worsens (measured by an increase in CDS spreads), there is a higher likelihood that a fund is susceptible to sustained outflows, relative to VNAV funds. This is consistent with Hypothesis 2, which predicts that a weakening of a sponsor's financial condition increases sustained outflows, because the value of the sponsor's implicit guarantee diminishes. However, the combined effect of the Sponsor CDS Change and Sponsor CDS Change * CNAV coefficients is close to zero, somewhat diminishing support for this hypothesis given that it is difficult to justify the relation between VNAV sustained outflows and sponsor financial strength.

In Euro-denominated funds, there is a relation between the presence of CDS data and the likelihood of sustained outflows for both VNAV and CNAV funds, since the coefficient on Sponsor CDS Data is positive and statistically significant. The only statistically significant and different relation between changes in sponsor strength and sustained outflows for CNAV funds is in High Return funds, where there is a negative, statistically significant coefficient on Sponsor CDS Change and a positive, statistically significant coefficient on $C N A V *$ Sponsor CDS Change. Again, this is subject to the same criticism discussed above for U.S. dollar funds.

The paper currently uses the presence of CDS data as a measure of fund sponsor financial strength. A fund sponsor's presence in other lines of business may also have an impact on risk-taking in money market funds and on the decision to provide an implicit guarantee since this may have an impact on the fund sponsor's reputation and impact their other lines of businesses. Similar to Kazpercyk and Schnabl (2012), Fund Business represents the proportion of the fund sponsor's mutual fund assets under management that are not in money market mutual funds as at August 2008. Non-Fund Business is a dummy variable that takes the value of one if the fund sponsor is part of a banking or insurance group. Both of these measures are demeaned by the average of the measure by fund currency and share price structure. The results using these measures are examined in Table 5. For U.S. dollar and Eurodenominated funds, there is no statistically significant relation between Fund Business and sustained 
outflows. Those funds with a larger Non-Fund Business are, however, less likely to experience sustained outflows. This could be consistent with less risk taking by these funds if this is interpreted as a measure of the risk taking in the fund. Alternatively, funds with more reputational concerns may be more likely to provide support for their funds so this is also consistent with that. However, the sign on the interaction term, CNAV* Non-Fund Business, negates this effect for CNAV funds such that there is no relation between Non-Fund Business and sustained outflows for CNAV funds.

\subsection{Fund liquidations and fund share price structure}

The share price structure of a fund could also affect whether a fund is ultimately liquidated. ${ }^{13}$ On the one hand, if CNAV funds are more susceptible to runs, this would suggest that they may also be more susceptible to being liquidated. On the other hand, CNAV funds may benefit more from an implicit guarantee from their sponsor, which would lower the probability that CNAV funds get liquidated.

In this subsection, I use a Cox (1972) proportional hazard model to examine the liquidation of money market funds, and the factors that are associated with a fund's liquidation. The Cox model can be used to examine a fund's liquidation in a panel setting with time-varying independent variables. I estimate the model on a daily basis, and estimate the likelihood that a fund will be liquidated on day $\mathrm{t}+1$ from the sample of funds that have not yet been liquidated on day $t$. Hence, a fund becomes a "failure" once it is liquidated and it is removed from the analysis in the time period after it has been liquidated. The instantaneous liquidation rate for fund $i$ is the hazard rate in the model and can be written as a function of the independent variables:

$$
h\left(t \mid x_{i}\right)=h_{0}(t) \exp \left(x_{i} B_{x}\right)
$$

The independent variables, $\mathrm{x}_{\mathrm{i}}$, include the $C N A V$ dummy, the logarithm of the fund's size, the Institutional dummy variable, the Sponsor CDS Data dummy variable, Fund Business, Non-Fund Business, and Outflows. Outflows is related to the measure of sustained outflows that we used as a dependent variable in earlier regressions. The dependent variable in previous regressions was equal to one if a fund experienced outflows greater than one percent of assets for three consecutive days. In this analysis, I calculate a moving, 30-day average of the fund outflows dummy variable. The 30-day window was chosen because there may be a time lag between the time when a fund decides to liquidate and the actual liquidation date. Funds that experience more sustained outflows should, all else equal, be more likely to be liquidated. To determine whether there is any difference in the behaviour of CNAV funds and

\footnotetext{
${ }^{13}$ The Cox analysis here includes fund closures due to fund mergers as a liquidation event. However, the results are very similar if mergers are excluded and only liquidations are used as a measure of a fund's failure.
} 
VNAV funds, the $C N A V$ dummy variable in this regression is interacted with both the Sponsor CDS Data dummy variable as well as with the Outflows measure and the Fund Business and Non-Fund Business variables.

I estimate the Cox proportional hazard model for U.S. dollar funds on the left side of Table 6 . Over the full daily sample period from June 2005 through Feb 2012, there are 277 funds in the survival analysis that could have been liquidated. Of these, 19 , or just over $5 \%$ of funds, were liquidated during the sample period. There is a statistically significant, positive relation between Outflows and fund liquidations: those funds that experience more sustained outflows over the previous 30 day period are more likely to be liquidated. CNAV funds, when there are no redemptions, are more likely to be liquidated relative to VNAV funds, as suggested by the statistical significance on the CNAV dummy variable.

More importantly, the coefficient on the interaction between CNAV and Outflows is negative and statistically significant. This is consistent with Hypothesis 3: if CNAV funds are more likely to receive sponsor support during a period of heavy redemptions, then we should expect to see a weaker relation between outflows and liquidations in CNAV funds. Moreover, the magnitude of this coefficient is just about half the magnitude of the coefficient associated with sustained outflows. This suggests that while there is a relation between sustained outflows and liquidations in VNAV funds, the relation between these two is much smaller in CNAV funds. Euro-denominated funds display a similar effect. There is no consistent evidence of a differential relation between sponsor characteristics and fund survival for CNAV funds.

\section{Robustness Tests}

An alternative method to measure the effect of the CNAV structure is to examine fund net inflows directly, rather than constructing a dummy variable measure of Sustained Outflows as has been done to this point. A test of Hypothesis 1 could be to measure whether there is a higher sensitivity of net inflows to negative performance in CNAV money market funds. This analysis uses the returns of money market mutual funds. For CNAV funds, these returns are based upon amortized cost accounting and hence do not represent the returns based on the fair market value of securities the fund is holding.

The flow-performance relation is examined at a daily frequency using a fixed effects panel regression that allows for autocorrelation in the disturbance term:

$$
\text { Net Inflow }_{i t}=\alpha+\beta_{1} \text { Net Inflow }_{i t-1}+\beta_{2} C N A V * \text { Net Inflow }_{i t-1}+\beta_{3} \Delta L I B O R-O I S
$$




$$
\begin{aligned}
& +\beta_{4} \text { CNAV }^{*} \triangle \text { LIBOR-OIS }+\beta_{5} \text { Lagged Return }^{+}+\beta_{6} \text { CNAV }^{*} \text { Lagged Return }^{+} \\
& +\beta_{7} \text { Lagged Return }^{-}+\beta_{8} \text { CNAV }^{*} \text { Lagged Return }^{-}+ \\
& +\beta_{9} \text { Average Flows }^{+} \beta_{10} \text { CNAV }^{*} \text { Average Flows } \\
& +\beta_{11} \text { Return Volatility }+v_{\mathrm{i}}+\varepsilon_{\mathrm{it}} \\
& \varepsilon_{\mathrm{it}}=\rho \varepsilon_{\mathrm{it}-1}+\eta_{\mathrm{it}}
\end{aligned}
$$

Fund fixed effects are included to control for fund characteristics that could have an impact on flows. For example, an additional dollar of flows would have a larger effect on percentage flows for smaller funds. As well, since differences in fund riskiness could lead to differences in flows as well, Return Volatility is included in the regression. ${ }^{14}$ This measures the volatility of the fund's return over the previous 30 trading days. Average Flows measures the average daily net inflows to funds with the same currency and pricing structure. The change in LIBOR-OIS spreads, $\triangle L I B O R$-OIS, is included to control for changes in spreads that could have an effect on flows to all funds. This is also interacted with the $C N A V$ dummy variable to allow for differences in the flow response to LIBOR-OIS between CNAV and VNAV funds. Lagged Return + is the excess daily return on a fund relative to the average return on funds. It is set to zero if excess returns are negative. Lagged Return - is similarly defined. A higher coefficient on Lagged Return -, relative to the coefficient on Lagged Return +, would be indicative of a higher sensitivity of flows to performance for VNAV funds. In fact, Table 7, column 1 shows that there is a higher sensitivity of flows to performance in poorly performing VNAV U.S. dollar funds, whereas there is no sensitivity of flows to performance in positively performing VNAV funds. For the High Return U.S. dollar and Euro-denominated funds, this pattern is even stronger for CNAV funds, given that there is a significant, positive coefficient on the CNAV* Lagged Excess Return - interaction term, suggesting that investors react more strongly to negative returns in these funds.

Lynch and Musto (2003) and Sirri and Tufano (1998) document a convex flow-performance relation using mutual fund flows, and Christoffersen (2001) finds a convex relation for money market fund flows. Essentially a convex flow-performance relation means that investors' flows are less sensitive to poor performance than they are to good performance. The results here are contrary to a convex-flow performance since flows are more sensitive to poor returns then they are to good returns. Some of this difference could be attributable to differences in the frequency of measurement, since this paper studies flows at a daily frequency while the others examine flows at a less frequent interval. As well, during the

\footnotetext{
${ }^{14}$ Return volatility is likely biased downward for CNAV funds since their returns are based upon amortized cost accounting values.
} 
sample period here, investors in money market funds are likely interested in preserving their capital and there is little upside in money market funds given that there are restrictions on the investment portfolio of money market funds. This may also explain why there is no reaction to positive excess returns, whereas there is an outflow when there are negative excess returns. The results for High Return U.S. dollar funds suggest a negative sensitivity of fund inflows to changes in the LIBOR-OIS spread. This makes sense since High Return funds are likely invested in more risky assets that should be related to LIBOR-OIS spreads so this is a better measure of performance for these funds.

So far, the analysis has examined sustained outflows as a proxy for run behaviour. An alternative interpretation of the earlier results is that flows in CNAV funds may just be more volatile, and this would manifest itself in a higher likelihood of sustained outflows and inflows for CNAV funds. ${ }^{15}$ As a robustness check, this section tests whether sustained inflows produce a similar result. Sustained inflows are defined similarly to sustained outflows: three consecutive days of net flows greater than $1 \%$ of net assets. These results are examined in Table 8. There is also a higher likelihood of sustained inflows for CNAV funds in the pre-crisis period as indicated by the positive and statistically significant coefficient on the $C N A V$ dummy variable. During the crisis period and the guarantee period, sustained inflows are not more likely to occur in CNAV funds. In fact, several of the coefficients on the interaction terms, $C N A V^{*}$ Crisis and CNAV* Guarantee and are statistically significant and negative. Therefore, these results cannot simply be attributed to higher volatility of flows for CNAV funds.

The U.S. dollar sample is dominated by funds domiciled in the United States that may lead to results that reflect the difference between U.S.-domiciled funds and non-U.S. domiciled funds, despite the presence of country dummy variables in the analysis. To address this concern, the U.S. dollar regression in Table 3 is re-run excluding funds domiciled in the United States (see Table 9). Most of the results from the earlier regression still stand. CNAV funds experience more outflows, especially in the period around the run on the Reserve Primary fund. There is no difference in behaviour during the Guarantee period, which is consistent with the fact that non-U.S. domiciled funds were not subject to the U.S. Treasury guarantee program.

This paper also utilizes a rather strict definition of CNAV funds, but this reduces the sample of CNAV funds in the analysis. But, the results may be different for a broader definition of CNAV funds

\footnotetext{
${ }^{15}$ There may exist an incentive to contribute to a CNAV fund if the price of the CNAV fund (i.e., \$1) is less than the market value of the underlying securities in the fund. In his research, Lyon (1984) finds that arbitrageur activity as a result of fund misvaluation results in both inflows and outflows. For U.S. dollar funds, the coefficient associated with the CNAV * LIBOR-OIS Change interaction term is positive and significant, indicating that CNAV funds have a higher likelihood of experiencing sustained inflows when LIBOR-OIS spreads increase. This is contrary to the idea of mispricing: there should be a lower likelihood of sustained inflows for CNAV funds when LIBOR-OIS rates increase because an increase in LIBOR-OIS rates indicates that the value of the portfolio is decreasing, and a fund with a constant NAV should not experience more inflows when the portfolio value decreases.
} 
that not only looks at funds with a stable net asset value but also those that use amortized cost accounting and accumulate distributions. I use changes in each fund's share price to detect the usage of amortized cost accounting. I classify funds whose daily price never decreases during the sample as constant NAV mutual funds according to this broader measure. Otherwise, the fund is considered a floating NAV fund. The results using this broader definition are examined in Table 9. For U.S. dollar funds, the results are similar to the earlier regressions. CNAV funds are more likely to experience outflows, even during the crisis period. During the Treasury guarantee period, U.S.-domiciled funds are still less likely (on a relative basis) to experience sustained outflows.

The results are only slightly weaker for Euro-denominated funds when compared to earlier regressions. ${ }^{16}$ The coefficients on the $C N A V$ dummy variable and the $C N A V *$ Crisis interactions terms are of a smaller magnitude but are both statistically significant. This suggests that there are some differences in outflow behaviour between CNAV funds defined using a more narrow definition where the NAV is maintained at a fixed price (e.g., \$1) and those defined using a more broad definition. The main difference between these two types of funds is whether they distribute income to maintain a stable share price or whether they accumulate income, resulting in an increasing share price. There should be no strong reason why the distribution policy itself should result in a difference in outflow behaviour. This small difference could be a result of several different factors. First, the broader definition may actually be capturing some funds that are, in reality, VNAV funds. The broader definition defined a fund as a CNAV fund if its price never decreased during our sample period, which could inadvertently result in some VNAV funds being classified as CNAV funds, resulting in a weaker relation (especially for Eurodenominated funds, where fewer funds fall under the more narrow definition of CNAV funds). Second, CNAV funds under the narrow definition may attract a different clientele of investors, who are more risk averse and hence are more likely to redeem their shares and transfer to a safer option such as a Treasuryonly money market fund.

The analysis to this point in the paper has relied on a specific measure of redemptions: three days of consecutive outflows greater than $1 \%$ of total assets. This measure was used because it overcame some of the data limitations in our sample, and because this measure also portrayed the run behaviour in September 2008 in the United States. But other measures should also be able to capture extreme outflows from money market funds, and in this section I test the results relative to another measure of outflows: daily outflows greater than $10 \%$. The results are also robust to this measure of runs. The coefficient on the CNAV dummy variable is positive, albeit a bit smaller in magnitude but it is still statistically significant.

\footnotetext{
${ }^{16}$ I also rerun the results within country/currency pairs and generally obtain similar results. For the broad definition, I investigated Luxembourg U.S. dollar and Euro-denominated funds as well as French Euro-denominated funds. For the narrow definition, I investigated U.S. dollar funds in the U.S. and Ireland, as well as Euro-denominated funds in Ireland.
} 
The coefficient on the interaction tern, $C N A V *$ Crisis, remains positive and statistically significant for U.S. dollar funds. During the Treasury guarantee period, the results are even stronger for U.S.-domiciled funds, with a larger negative coefficient (and statistically significant).

\section{Concluding Remarks}

The purpose of this paper was to investigate the relation between money market funds' use of the constant price structure and fragility in these funds. Overall, I find that funds using this structure experience a more frequent occurrence of sustained outflows, relative to VNAV mutual funds. This paper also illustrates the effectiveness of the U.S. Treasury's money market fund guarantee program, by comparing outflow behaviour in the U.S. during the period of the guarantee to outflow behaviour of VNAV and CNAV U.S. dollar funds domiciled in other countries not covered by the guarantee. During this period, sustained outflows in U.S.-domiciled funds were reduced relative to outflows in non-U.S.domiciled U.S. dollar money market funds.

If CNAV funds benefit more from an implicit guarantee from their fund sponsor, this will also likely have an effect on their survival. That is, if a fund sponsor is likely to step in and provide an implicit guarantee of the CNAV fund's share price should the fund underperform, then the fund's chances of survival should also increase as a result of this implicit guarantee. This paper finds that CNAV funds are less frequently liquidated after a period of heavy redemptions, which is suggestive of an implicit guarantee for CNAV funds and the lack of such a guarantee in VNAV funds.

This paper has several important policy implications. There is an active push to reform money market mutual funds in the wake of the financial crisis and more specifically following the run on the Reserve Primary Fund and subsequent government support of money market funds in the United States. One of the primary proposals is to move away from the CNAV money market fund structure and towards the VNAV structure. Some observers have contended that such a move does little to reduce the occurrence of runs in money market mutual funds, based on anecdotal evidence of run behaviour in ultrashort bond funds in the United States and enhanced money market funds in Europe, both of which maintain a VNAV structure (Investment Company Institute, 2011; HSBC, 2011). These funds, however, are not subject to the same liquidity, credit, and maturity restrictions as money market funds. This paper compares a large number of money market mutual funds across several countries and finds that, on the contrary, the VNAV structure is less susceptible to run-like behaviour relative to CNAV money market funds. 
However, the VNAV structure does not fully eliminate this run-like behaviour. This is consistent with the model of Chen, Goldstein, and Jiang (2011), which shows that mutual funds holding illiquid assets experience more outflows following a period of poor performance, relative to funds holding liquid assets (their empirical examination focuses on equity mutual funds). That is, in their model investors may redeem on the self-fulfilling belief that others will be redeeming, imposing the costs of liquidating the fund's illiquid assets on remaining shareholders. While money market funds generally hold liquid, shortterm assets, these assets may become illiquid during periods of stress or, put another way, during periods when there is a belief that a fire sale of some money market fund holdings may occur. ${ }^{17}$ Even during periods of stress, however, CNAV money market funds are more prone to run-like behaviours, relative to VNAV money market funds.

Not only does the CNAV structure have a higher occurrence of sustained outflows, but also there is some evidence to suggest that it is associated with an implicit guarantee provided by fund sponsors. This implicit guarantee has both advantages and disadvantages. The presence of an implicit guarantee can reduce moral hazard and reduce risk-taking in money market mutual funds, since the fund sponsor would be concerned that the poor performance of the fund may have negative spillovers on the sponsor's other businesses (Kazpercyk and Schnabl, 2012). The amount of risk-taking depends upon both the sponsor's financial strength as well as the reputational concerns about the effect of "breaking the buck" on the rest of the sponsor's fund and non-fund businesses. On the other hand, an implicit guarantee is a potential channel for contagion between the banking sector and money market mutual funds. Losses in a money market mutual fund may be passed onto the fund sponsors should they provide support to the fund. As well, a weakening of a fund sponsor could be passed onto the money market fund sector through a reduction in the value of the implicit guarantee.

\footnotetext{
${ }^{17}$ Even in normal times, the secondary market for commercial paper is generally thin. Most of the liquidity is provided by dealers, who face their own liquidity and capital pressures during times of stress (Duygan-Bump et al, 2012; Covitz and Downing, 2007).
} 
Appendix A. Variable descriptions.

\begin{tabular}{|c|c|}
\hline CNAV & $\begin{array}{l}\text { A money market mutual fund is defined as a CNAV fund if it maintains a fixed share } \\
\text { price of } \$ 1 \text { or } \$ 10 \text {, or if it has never experienced a decline in its net asset value. } \\
\text { Otherwise, the fund is considered to be a VNAV fund. }\end{array}$ \\
\hline Institutional & $\begin{array}{l}\text { This dummy variable is set equal to } 1 \text { if the fund is a fund serving institutional investors. } \\
\text { A fund is classified as institutional if its largest share class is classified as institutional } \\
\text { according to Morningstar. This information is available for most, but not all funds. For } \\
\text { those funds without a Morningstar Institutional classification, they are classified as } \\
\text { institutional if the minimum required investment is greater than } € 100,000 \text { or } \$ 100,000 \text {, } \\
\text { depending on the fund's currency. As well, if the fund's largest share class is a class of } \\
\text { type I, it is classified as institutional. }\end{array}$ \\
\hline Ln (Fund Size) & $\begin{array}{l}\text { This is the logarithm of the fund's assets under management, measured at a daily } \\
\text { frequency. }\end{array}$ \\
\hline LIBOR-OIS Change & This variable measures the three day change in the LIBOR-OIS spread. \\
\hline EURIBOR-OIS Change & This variable measures the three day change in the EURIBOR-OIS spread. \\
\hline Sponsor CDS Data & $\begin{array}{l}\text { This is a dummy variable that takes the value of } 1 \text { if the fund sponsor has an available } \\
\text { CDS price reported by Markit. }\end{array}$ \\
\hline Sponsor CDS Change & $\begin{array}{l}\text { This variable is equal to the } 3 \text {-day change in the fund sponsor's } 5 \text { year CDS spread } \\
\text { reported by Markit. CDS data is for US Dollar contracts. For firms where US Dollar } \\
\text { contract data is unavailable, Euro contracts are used. If the fund sponsor does not have } \\
\text { any CDS data reported by Markit, the change is set equal to zero. }\end{array}$ \\
\hline Flow & This variable equals the net inflows to the money market fund, scaled by the fund size. \\
\hline Liquidate & $\begin{array}{l}\text { This is a dummy variable that takes the value of } 1 \text { if the fund was liquidated during the } \\
\text { sample period. }\end{array}$ \\
\hline Pre-Crisis & A dummy variable that is equal to one prior to September $1,2008$. \\
\hline Crisis & $\begin{array}{l}\text { A dummy variable that is equal to one from September 1, } 2008 \text { through September } 30^{\text {th }} \text {, } \\
2008 \text {, and zero otherwise. }\end{array}$ \\
\hline Guarantee & $\begin{array}{l}\text { A dummy variable that is equal to one during the period from September } 20^{\text {th }}, 2008 \\
\text { through September } 18^{\text {th }}, 2009 \text {, and zero otherwise. This corresponds to the time when } \\
\text { the U.S. Treasury provided a guarantee for U.S. money market mutual funds. }\end{array}$ \\
\hline Post Guarantee & $\begin{array}{l}\text { A dummy variable that is equal to one during the period from September } 20^{\text {th }}, 2009 \\
\text { onwards, and zero otherwise. }\end{array}$ \\
\hline Low Return Funds & $\begin{array}{l}\text { Those funds whose return over the period from August } 2007 \text { through August } 2008 \text { was } \\
\text { below the return of the median fund with the same currency and share price structure } \\
\text { (e.g., the median return for U.S. dollar CNAV funds). }\end{array}$ \\
\hline High Return Funds & $\begin{array}{l}\text { Those funds whose return over the period from August } 2007 \text { through August } 2008 \text { was } \\
\text { above the return of the median fund with the same currency and share price structure } \\
\text { (e.g., the median return for U.S. dollar CNAV funds). }\end{array}$ \\
\hline Return volatility & $\begin{array}{l}\text { This measure is the standard deviation of the returns of the fund over the previous } 30 \\
\text { trading days. }\end{array}$ \\
\hline Average Flows & $\begin{array}{l}\text { This variable measures the average daily net inflows to funds with the same currency } \\
\text { and pricing structure. }\end{array}$ \\
\hline Fund Business & $\begin{array}{l}\text { Fund Business represents the proportion of the fund sponsor's mutual fund assets under } \\
\text { management that are not in money market mutual funds as at August } 2008 \text {. It is } \\
\text { demeaned by the average of Fund Business by fund currency and share price structure. }\end{array}$ \\
\hline Non-Fund Business & $\begin{array}{l}\text { Non-Fund Business is a dummy variable that takes the value of one if the fund sponsor } \\
\text { is part of a banking or insurance group. It is demeaned by the average of Non-Fund } \\
\text { Business by fund currency and share price structure. }\end{array}$ \\
\hline
\end{tabular}




\section{References}

Bengtsson, E., 2011. Shadow banking and financial stability: European money market funds in the global financial crisis. Sveriges Riksbank Working paper.

Bernardo, A., Welch, I., 2004. Liquidity and financial market runs. Quarterly Journal of Economics 119, 135-158.

Chalmers, J., Edelen, R., Kadlec, G., 2001. On the perils of financial intermediaries setting security prices: the mutual fund wild card option. Journal of Finance 56, 2209-2235.

Chen, Q., Goldstein, I., Jiang, W., 2010. Payoff complementarities and financial fragility: evidence from mutual fund outflows. Journal of Financial Economics 97, 239-262.

Cherkes, M., Sagi, J., Stanton, R., 2006. A liquidity-based theory of closed-end funds. Working Paper, University of California at Berkeley.

Chernenko, S., Sunderam, A., 2011. The quiet run of 2011: money market funds and the European debt crisis. Unpublished Working Paper.

Chevalier, J., Ellison, G., 1997. Risk taking by mutual funds as a response to incentives. Journal of Political Economy 105, 1167-1200.

Chordia, T., 1996. The structure of mutual fund charges. Journal of Financial Economics 41, 3-39.

Christoffersen, S., 2001. Why do money fund managers voluntarily waive their fees? Journal of Finance $56,117-1140$.

Covitz, D., Downing, C., 2007. Liquidity or credit risk? The determinants of very short-term corporate yield spreads. Journal of Finance 62, 2308-2328.

Diamond, D.W., Dybvig, P.H., 1983. Bank runs, deposit insurance, and liquidity. Journal of Political Economy.

Duygan-Bump, B., Parkinson, P., Rosengren, E., Suarez, G., Willen, S., 2012. How effective were the Federal Reserve emergency liquidity facilities? Evidence from the asset-backed commercial paper money market mutual fund liquidity facility. Journal of Finance, forthcoming.

Edelen, R., 1999. Investor flows and the assessed performance of open-end mutual funds. Journal of Financial Economics 53, 439-466.

European Fund and Asset Management Association, 2011. International statistical release Q3 2011, supplementary table S4.

Fernando, D., Klapper, L., Sulla, V., Vittas, D., 2003. The global growth of mutual funds. World Bank Policy Research Working Paper 3055.

FINRA, 2010. Treasury's guarantee program for money market mutual funds: what you should know. July. 
Fisch, J., Roiter, E., 2011. A floating NAV for money market funds: fix or fantasy? University of Pennsylvania Law School Research Paper No 11-30.

Gorton, G., Pennacchi, G., 1992. Money market funds and finance companies: are they the banks of the future? Structural Change in Banking, 173-214.

Greene, J.T., Hodges, C.W., 2002. The dilution impact of daily fund flows on open-end mutual funds. Journal of Financial Economics 65, 131-159.

HSBC, 2011. Run risk in money market funds.

Investment Company Institute, 2012. A bad idea: forcing money market funds to float their NAVs.

Jank, S., Wedow, M., 2010. Sturm und drang in money market funds: when money market funds cease to be narrow. Unpublished Working Paper.

Kacperczyk, M., Schnabl, P., 2012. How safe are money market funds? AFA 2012 Chicago Meetings paper.

Lyon, A.B., 1984. Money market funds and shareholder dilution. Journal of Finance 39, 1011-1020.

Massa, M., Rehman, Z., 2008. Information flows within financial conglomerates: evidence from the banks-mutual funds relationship.

McCabe, P., 2010. The cross section of money market fund risks and financial crises. Finance and Economics Discussion Series 2010-51, Board of Governors of the Federal Reserve System.

Miles, W., 2001. Can money market funds provide sufficient liquidity to replace deposit insurance? Jounral of Economics and Finance 25, 328-342.

Money Market Working Group, 2011. Report of the Money Market Working Group.

Nanda, V., Narayanan, M., Warther, V., 2000. Liquidity, investment ability, and mutual fund structure. Journal of Financial Economics 57, 417-443.

Pennacchi, G., 2006. Deposit insurance, bank regulation, and financial system risks. Journal of Monetary Economics 53, 1-30.

Rakowski, D., Wang, X., 2009. The dynamics of short-term mutual fund flows and returns: a time series and cross-sectional investigation. Journal of Banking and Finance.

Shilling, H., 2010. Sponsor support key to money market funds. Moody's Investor Service Special Comment (August 9, 2010).

Sirri, E., Tufano, P. 1998. Costly search and mutual fund flows. Journal of Finance 53, 1589-1622.

Stein, J., 2005. Why are most funds open-end? Competition and the limits of arbitrage. Quarterly Journal of Economics 120, 247-272.

Squam Lake Group, 2011. Reforming money market funds. Unpublished Working Paper. 
Technical Committee of the International Organization of Securities Commissions, 2012. Money market fund systemic risk analysis and reform options. Consultation Report CR07/12.

Zitzewitz, E., 2003. Who cares about shareholders? Arbitrage-proofing mutual funds. Journal of Law, Economics and Organization 19, 245-279. 


\section{Table 1}

Summary Statistics.

This table reports summary statistics for both constant net asset value (CNAV) and variable net asset value (VNAV) non-government money market mutual funds in the United States and several European countries. A money market mutual fund is defined as a CNAV fund if it maintains a fixed share price of $\$ 1$ or $\$ 10$, or if it has never experienced a decline in its net asset value. Otherwise, the fund is considered to be a VNAV fund. This table displays the proportion of VNAV funds that are classified as Low Variability and High Variability. Funds are classified as low variability VNAV funds if between zero and five percent of the fund's daily price changes are negative. It is classified as high variability if greater than $5 \%$ of these price changes are negative.

\begin{tabular}{|c|c|c|c|c|c|c|c|c|}
\hline \multicolumn{9}{|c|}{ Panel A: Euro-denominated money market mutual funds } \\
\hline \multirow[b]{2}{*}{ Belgium } & & $\begin{array}{c}\text { Number } \\
\text { of } \\
\text { Funds }\end{array}$ & $\begin{array}{c}\text { Number of } \\
\text { Institutional } \\
\text { Funds }\end{array}$ & $\begin{array}{c}\text { Average } \\
\text { Fund } \\
\text { Size } \\
(€ M)\end{array}$ & $\begin{array}{c}\text { Total } \\
\text { Fund } \\
\text { Assets } \\
(€ B)\end{array}$ & $\begin{array}{c}\text { Low } \\
\text { Variability } \\
\text { VNAV } \\
\text { Funds }\end{array}$ & $\begin{array}{c}\text { Medium } \\
\text { Variability } \\
\text { VNAV } \\
\text { Funds }\end{array}$ & $\begin{array}{c}\text { High } \\
\text { Variability } \\
\text { VNAV } \\
\text { Funds }\end{array}$ \\
\hline & $V N A V$ & 3 & 0 & 331 & 0.99 & $0.0 \%$ & $66.6 \%$ & $33.3 \%$ \\
\hline rimiand & $V N A V$ & 1 & 0 & 374 & 0.37 & $0.0 \%$ & $0.0 \%$ & $100.0 \%$ \\
\hline rrance & $V N A V$ & 262 & 23 & 1076 & 282 & $49.4 \%$ & $42.6 \%$ & $8.0 \%$ \\
\hline (5) & $V N A V$ & 5 & 0 & 267 & 1.33 & $0.0 \%$ & $40.0 \%$ & $60.0 \%$ \\
\hline & $\begin{array}{l}V N A V \\
C N A V\end{array}$ & $\begin{array}{c}5 \\
11\end{array}$ & $\begin{array}{l}2 \\
4\end{array}$ & $\begin{array}{c}337 \\
3,798\end{array}$ & $\begin{array}{c}1.68 \\
41.77\end{array}$ & $0.0 \%$ & $20.0 \%$ & $80.0 \%$ \\
\hline & $V N A V$ & 1 & 0 & 377 & 0.38 & $0.0 \%$ & $0.0 \%$ & $100.0 \%$ \\
\hline & $\begin{array}{l}V N A V \\
C N A V\end{array}$ & $\begin{array}{c}55 \\
1\end{array}$ & $\begin{array}{c}13 \\
1\end{array}$ & $\begin{array}{c}991 \\
20,689\end{array}$ & $\begin{array}{c}54.5 \\
20.69\end{array}$ & $7.3 \%$ & $56.4 \%$ & $36.4 \%$ \\
\hline spain & $V N A V$ & 53 & 2 & 172 & 9.1 & $3.7 \%$ & $16.7 \%$ & $79.6 \%$ \\
\hline Switzerland & $V N A V$ & 4 & 1 & 1059 & 4.24 & $0.0 \%$ & $25.0 \%$ & $75.0 \%$ \\
\hline
\end{tabular}


Table 1 (continued)

\begin{tabular}{|c|c|c|c|c|c|c|c|c|}
\hline \multicolumn{9}{|c|}{ Panel B: U.S. dollar-denominated money market mutual funds } \\
\hline & & $\begin{array}{c}\text { Number } \\
\text { of } \\
\text { Funds }\end{array}$ & $\begin{array}{c}\text { Number of } \\
\text { Institutional } \\
\text { Funds }\end{array}$ & $\begin{array}{c}\text { Average } \\
\text { Fund } \\
\text { Size } \\
\text { (\$M) }\end{array}$ & $\begin{array}{c}\text { Total } \\
\text { Fund } \\
\text { Assets } \\
\text { (\$B) }\end{array}$ & $\begin{array}{c}\text { Low } \\
\text { Variability } \\
\text { VNAV } \\
\text { Funds }\end{array}$ & $\begin{array}{c}\text { Medium } \\
\text { Variability } \\
\text { VNAV } \\
\text { Funds }\end{array}$ & $\begin{array}{c}\text { High } \\
\text { Variability } \\
\text { VNAV } \\
\text { Funds }\end{array}$ \\
\hline & $V N A V$ & 1 & 0 & 74 & 0.07 & $0.0 \%$ & $0.0 \%$ & $100.0 \%$ \\
\hline France & $V N A V$ & 7 & 1 & 65 & 0.45 & $14.3 \%$ & $71.4 \%$ & $14.3 \%$ \\
\hline 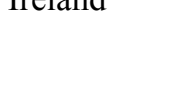 & $\begin{array}{l}V N A V \\
C N A V\end{array}$ & $\begin{array}{c}6 \\
11\end{array}$ & $\begin{array}{l}2 \\
7\end{array}$ & $\begin{array}{l}1,007 \\
5,758\end{array}$ & $\begin{array}{c}6.0 \\
63.3\end{array}$ & $16.7 \%$ & $50.0 \%$ & $33.3 \%$ \\
\hline Italy & $V N A V$ & 1 & 0 & 260 & 0.26 & $0.0 \%$ & $0.0 \%$ & $100.0 \%$ \\
\hline & $\begin{array}{l}V N A V \\
C N A V\end{array}$ & $\begin{array}{c}32 \\
3\end{array}$ & $\begin{array}{l}5 \\
1\end{array}$ & $\begin{array}{c}595 \\
24,846\end{array}$ & $\begin{array}{l}19.1 \\
74.5\end{array}$ & $6.3 \%$ & $46.9 \%$ & $46.9 \%$ \\
\hline & $V N A V$ & 4 & 0 & 2,292 & 9.17 & $0.0 \%$ & $25.0 \%$ & $75.0 \%$ \\
\hline & $\begin{array}{l}V N A V \\
C N A V\end{array}$ & $\begin{array}{c}7 \\
175 \\
\end{array}$ & $\begin{array}{c}5 \\
77\end{array}$ & $\begin{array}{l}1,949 \\
5,055\end{array}$ & $\begin{array}{r}13.6 \\
884.8 \\
\end{array}$ & $0.0 \%$ & $84.6 \%$ & $15.4 \%$ \\
\hline
\end{tabular}




\section{Table 2}

Summary Statistics on proportion of sustained outflows.

This table reports the proportion of sustained outflows for both constant net asset value (CNAV) and variable net asset value (VNAV) non-government money market mutual funds in the United States and several European countries. The variable that this table measures is sustained outflows. A fund is considered to experience sustained outflows if it sustains net outflows of $1 \%$ (as a proportion of fund size) or larger for three consecutive trading days. The measures reported in the table represent the proportion of daily observations during each sub-period when a fund experienced sustained outflows.

\begin{tabular}{|c|c|c|c|c|c|}
\hline & & Pre-Crisis & Crisis & $\begin{array}{l}\text { Guarantee } \\
\text { Period }\end{array}$ & $\begin{array}{c}\text { Post-Guarantee } \\
\text { Period }\end{array}$ \\
\hline \multirow{2}{*}{$\begin{array}{l}\text { U.S. Dollar, U.S.- } \\
\text { based }\end{array}$} & & $\begin{array}{c}\text { January } 1,2006- \\
\text { August } 31,2008\end{array}$ & $\begin{array}{l}\text { September 1, } 2008 \text { - } \\
\text { September 30, } 2008\end{array}$ & $\begin{array}{l}\text { Sept } 20,2008- \\
\text { Sept } 18,2009\end{array}$ & $\begin{array}{c}\text { Sept 19, 2009- } \\
\text { December 31, } 2011\end{array}$ \\
\hline & $\begin{array}{l}V N A V \\
C N A V\end{array}$ & $\begin{array}{l}0.019 \\
0.012\end{array}$ & $\begin{array}{l}0.020 \\
0.053\end{array}$ & $\begin{array}{l}0.003 \\
0.012\end{array}$ & $\begin{array}{l}0.006 \\
0.010\end{array}$ \\
\hline \multicolumn{6}{|c|}{$\begin{array}{l}\text { U.S. Dollar, European } \\
\text {-based }\end{array}$} \\
\hline \multirow{2}{*}{ Euro-denominated } & $\begin{array}{l}\text { VNAV } \\
\text { CNAV }\end{array}$ & $\begin{array}{l}0.003 \\
0.013\end{array}$ & $\begin{array}{l}0.015 \\
0.118\end{array}$ & $\begin{array}{l}0.009 \\
0.028\end{array}$ & $\begin{array}{l}0.004 \\
0.018\end{array}$ \\
\hline & $\begin{array}{l}\text { VNAV } \\
\text { CNAV }\end{array}$ & $\begin{array}{l}0.006 \\
0.012 \\
\end{array}$ & $\begin{array}{l}0.006 \\
0.067\end{array}$ & $\begin{array}{l}0.006 \\
0.017\end{array}$ & $\begin{array}{l}0.007 \\
0.020\end{array}$ \\
\hline
\end{tabular}


Table 3

Panel logit regressions describing outflow behaviour.

The dependent variable in these panel logit regressions is a dummy variable that is equal to one whenever a fund sustains net outflows of $1 \%$ of fund assets or larger for three consecutive trading days. Absolute value of $\mathrm{z}$ statistics are in parentheses. * indicates statistical significance at the $10 \%$ threshold; ** indicates statistical significance at the $5 \%$ threshold; and $* * *$ indicates statistical significance at the $1 \%$ threshold.

\begin{tabular}{|c|c|c|c|c|c|c|}
\hline & \multicolumn{3}{|c|}{ US Dollar } & \multicolumn{3}{|c|}{ Euro } \\
\hline & $\underline{\text { All }}$ & $\stackrel{\text { Low }}{\text { Return }}$ & $\frac{\text { High }}{\text { Return }}$ & $\underline{\text { All }}$ & $\frac{\text { Low }}{\text { Return }}$ & $\frac{\text { High }}{\text { Return }}$ \\
\hline \multirow{2}{*}{ CNAV } & 1.362 & 4.101 & -0.073 & 0.947 & -0.325 & 2.298 \\
\hline & $(2.92)^{* * *}$ & $(4.28)^{* * *}$ & $(0.12)$ & $(1.32)$ & $(0.25)$ & $(2.22)^{* *}$ \\
\hline \multirow{2}{*}{ Institutional } & 1.515 & 1.755 & 1.200 & 1.036 & 1.874 & 0.403 \\
\hline & $(6.70)^{* * *}$ & $(4.50)^{* * *}$ & $(4.51)^{* * *}$ & $(3.85)^{* * *}$ & $(2.84)^{* * *}$ & $(1.45)$ \\
\hline \multirow[t]{2}{*}{ Ln (Fund Size) } & -0.053 & -0.194 & 0.060 & 0.053 & -0.046 & 0.136 \\
\hline & $(1.46)$ & $(3.70)^{* * *}$ & $(1.17)$ & $(1.92)^{*}$ & $(1.37)$ & $(3.56)^{* * *}$ \\
\hline \multirow[t]{2}{*}{ Crisis } & 0.772 & 0.685 & 1.167 & -0.119 & -0.459 & 0.074 \\
\hline & $(2.71)^{* * *}$ & $(1.47)$ & $(3.13)^{* * *}$ & $(0.72)$ & $(1.47)$ & $(0.38)$ \\
\hline \multirow[t]{2}{*}{ CNAV * Crisis } & 0.857 & 0.902 & 0.477 & 2.005 & 2.761 & 1.169 \\
\hline & $(2.82)^{* * *}$ & $(1.80)^{*}$ & $(1.20)$ & $(6.17)^{* * *}$ & $(5.85)^{* * *}$ & $(2.27)^{* *}$ \\
\hline \multirow[t]{2}{*}{ Guarantee Date } & 0.767 & 1.193 & 0.171 & -0.055 & 0.120 & -0.181 \\
\hline & $(5.48)^{* * *}$ & $(5.37)^{* * *}$ & $(0.75)$ & $(0.87)$ & $(1.21)$ & $(2.19)^{* *}$ \\
\hline \multirow[t]{2}{*}{ CNAV * Guarantee } & -0.039 & -0.982 & 0.945 & 0.243 & 0.207 & 0.119 \\
\hline & $(0.22)$ & $(3.27)^{* * *}$ & $(3.34)^{* * *}$ & $(1.15)$ & $(0.74)$ & $(0.35)$ \\
\hline \multirow[t]{2}{*}{ US * CNAV * Guarantee } & -0.522 & -0.013 & -0.874 & & & \\
\hline & $(3.81)^{* * *}$ & $(0.06)$ & $(3.94)^{* * *}$ & & & \\
\hline \multirow[t]{2}{*}{ Post Guarantee } & -0.122 & 0.326 & -0.385 & 0.277 & -0.200 & 0.438 \\
\hline & $(0.83)$ & $(1.34)$ & $(1.94)^{*}$ & $(5.63)^{* * *}$ & $(2.22)^{* *}$ & $(7.26)^{* * *}$ \\
\hline \multirow[t]{2}{*}{ CNAV * Post Guarantee } & 0.286 & -0.483 & 0.727 & 0.152 & 0.864 & -0.364 \\
\hline & $(1.75)^{*}$ & $(1.78)^{*}$ & $(3.24)^{* * *}$ & $(0.82)$ & $(3.36)^{* * *}$ & $(1.30)$ \\
\hline \multirow[t]{2}{*}{ LIBOR-OIS $\Delta$} & 1.056 & 1.246 & 0.961 & 1.676 & 2.204 & 1.487 \\
\hline & $(2.29) * *$ & $(1.77)^{*}$ & $(1.29)$ & $(4.48)^{* * *}$ & $(3.67) * * *$ & $(3.07)^{* * *}$ \\
\hline \multirow[t]{2}{*}{ CNAV $*$ LIBOR-OIS $\Delta$} & -0.240 & -1.982 & 0.402 & -2.811 & -5.531 & 2.037 \\
\hline & $(0.48)$ & $(2.50)^{* *}$ & $(0.51)$ & $(2.13)^{* *}$ & $(3.10)^{* * *}$ & $(1.15)$ \\
\hline \multirow[t]{2}{*}{ Constant } & -6.632 & -6.696 & -7.098 & -7.650 & -6.148 & -9.231 \\
\hline & $(7.87)^{* * *}$ & $(4.75)^{* * *}$ & $(6.07)^{* * *}$ & $(7.40)^{* * *}$ & $(4.05)^{* * *}$ & $(7.07)^{* * *}$ \\
\hline Observations & 227,549 & 100,916 & 104,664 & 389,879 & 204,094 & 169,613 \\
\hline Number of funds & 296 & 125 & 127 & 471 & 217 & 218 \\
\hline
\end{tabular}


Table 4

Panel logit regressions describing outflow behaviour and sponsor financial strength.

The dependent variable in these panel logit regressions is a dummy variable that is equal to one whenever a fund sustains outflows of $1 \%$ of fund assets or larger for three consecutive trading days. This regression includes a dummy variable, Sponsor CDS Data, that takes the value of 1 if the fund sponsor has an available CDS price reported by Markit. Sponsor CDS Change is equal to the 3-day change in the sponsor's CDS spread. Standard errors are clustered at the fund level in the fixed effects regressions. Absolute value of $\mathrm{z}$ statistics are in parentheses. * indicates statistical significance at the $10 \%$ threshold; $* *$ indicates statistical significance at the $5 \%$ threshold; and $* * *$ indicates statistical significance at the $1 \%$ threshold.

\begin{tabular}{|c|c|c|c|c|}
\hline \multicolumn{5}{|l|}{ Panel A: U.S. Dollar Funds } \\
\hline \multirow{3}{*}{ CNAV } & All & All & Low Return & High Return \\
\hline & $1 . \overline{379}$ & & & \\
\hline & $(2.46)^{* *}$ & & & \\
\hline \multirow[t]{2}{*}{ Institutional } & 1.429 & & & \\
\hline & $(6.11)^{* * *}$ & & & \\
\hline \multirow{2}{*}{ Ln (Fund Size) } & -0.059 & -0.188 & -0.171 & -0.046 \\
\hline & (1.64) & $(1.92)^{*}$ & $(1.23)$ & $(0.34)$ \\
\hline \multirow{2}{*}{ Crisis } & 0.774 & 0.712 & -1.262 & 1.320 \\
\hline & $(2.73)^{* * *}$ & $(1.46)$ & $(0.90)$ & $(3.19)^{* * *}$ \\
\hline \multirow[t]{2}{*}{ CNAV * Crisis } & 0.857 & 1.103 & 2.890 & 0.536 \\
\hline & $(2.83)^{* * *}$ & $(2.05)^{* *}$ & $(1.99)^{* *}$ & $(1.03)$ \\
\hline \multirow[t]{2}{*}{ Guarantee Date } & 0.758 & 0.478 & 0.926 & 0.032 \\
\hline & $(5.40)^{* * *}$ & $(1.42)$ & $(1.68)^{*}$ & $(0.12)$ \\
\hline \multirow[t]{2}{*}{ CNAV * Guarantee Date } & -0.028 & 0.439 & -0.186 & 0.993 \\
\hline & $(0.15)$ & (1.14) & $(0.26)$ & $(2.69)^{* * *}$ \\
\hline \multirow[t]{2}{*}{ US * CNAV * Guarantee Date } & -0.521 & -0.606 & -0.475 & -0.813 \\
\hline & $(3.80)^{* * *}$ & $(2.55)^{* *}$ & $(0.98)$ & $(2.66)^{* * *}$ \\
\hline \multirow[t]{2}{*}{ Post Guarantee } & -0.126 & -0.093 & 0.189 & -0.333 \\
\hline & $(0.86)$ & $(0.39)$ & $(0.62)$ & $(1.22)$ \\
\hline \multirow[t]{2}{*}{ CNAV * Post Guarantee } & 0.293 & 0.266 & -0.412 & 0.737 \\
\hline & $(1.78)^{*}$ & $(0.87)$ & $(1.06)$ & $(1.99)^{* *}$ \\
\hline \multirow[t]{2}{*}{ LIBOR-OIS Change } & 1.130 & 0.581 & 1.580 & 0.707 \\
\hline & $(2.45)^{* *}$ & $(0.51)$ & $(0.68)$ & $(0.75)$ \\
\hline \multirow[t]{2}{*}{ CNAV * LIBOR-OIS Change } & -0.327 & 0.265 & -2.159 & 1.273 \\
\hline & $(0.65)$ & $(0.22)$ & $(0.89)$ & (1.19) \\
\hline \multirow{2}{*}{ Sponsor CDS Data } & 0.397 & & & \\
\hline & $(0.86)$ & & & \\
\hline \multirow{2}{*}{ CNAV * Sponsor CDS Data } & -0.072 & & & \\
\hline & $(0.14)$ & & & \\
\hline \multirow{2}{*}{ Sponsor CDS Change } & -0.861 & -0.945 & -1.498 & -0.963 \\
\hline & $(1.85)^{*}$ & $(3.48)^{* * *}$ & $(2.56)^{* *}$ & $(7.07)^{* * *}$ \\
\hline \multirow[t]{2}{*}{ CNAV * Sponsor CDS Change } & 0.885 & 0.955 & 1.495 & 0.878 \\
\hline & $(1.89)^{*}$ & $(3.44)^{* * *}$ & $(2.54)^{* *}$ & $(3.62)^{* * *}$ \\
\hline \multirow[t]{2}{*}{ Constant } & -6.612 & & & \\
\hline & $(7.44)^{* * *}$ & & & \\
\hline & 227,549 & 80,949 & 36,374 & 38,208 \\
\hline \multirow[t]{2}{*}{ Number of funds } & 296 & 98 & 43 & 44 \\
\hline & $\mathrm{RE}$ & FE & FE & FE \\
\hline
\end{tabular}




\begin{tabular}{|c|c|c|c|c|}
\hline \multicolumn{5}{|l|}{ Panel B: Euro Funds } \\
\hline \multirow[b]{2}{*}{ CNAV } & $\underline{\text { All }}$ & $\underline{\text { All }}$ & Low Return & High Return \\
\hline & $\begin{array}{l}0.953 \\
(0.97)\end{array}$ & & & \\
\hline \multirow[t]{2}{*}{ Institutional } & 0.944 & & & \\
\hline & $(3.61)^{* * *}$ & & & \\
\hline \multirow[t]{2}{*}{ Ln (Fund Size) } & 0.060 & 0.085 & -0.052 & 0.231 \\
\hline & $(2.16)^{* *}$ & $(0.59)$ & $(0.57)$ & (1.19) \\
\hline \multirow[t]{2}{*}{ Crisis } & -0.273 & -0.056 & -0.623 & 0.206 \\
\hline & $(1.63)$ & $(0.20)$ & $(1.22)$ & $(0.67)$ \\
\hline \multirow[t]{2}{*}{ CNAV * Crisis } & 1.962 & 1.317 & 1.782 & 1.027 \\
\hline & $(6.02)^{* * *}$ & $(3.27)^{* * *}$ & $(2.26)^{* *}$ & $(2.47)^{* *}$ \\
\hline \multirow[t]{2}{*}{ Guarantee Date } & 0.496 & -0.090 & 0.289 & -0.253 \\
\hline & $(5.45)^{* * *}$ & $(0.46)$ & $(0.80)$ & (1.40) \\
\hline \multirow[t]{2}{*}{ CNAV * Guarantee Date } & 0.194 & 0.237 & 0.105 & 0.181 \\
\hline & $(0.91)$ & (1.04) & $(0.24)$ & $(0.92)$ \\
\hline \multirow{2}{*}{ Post Guarantee } & 1.374 & 0.312 & -0.091 & 0.419 \\
\hline & $(10.02)^{* * *}$ & $(2.45)^{* *}$ & $(0.35)$ & $(3.40)^{* * *}$ \\
\hline \multirow[t]{2}{*}{ CNAV * Post Guarantee } & 0.133 & -0.069 & 0.828 & -0.517 \\
\hline & $(0.73)$ & $(0.28)$ & $(2.06)^{* *}$ & $(1.91)^{*}$ \\
\hline \multirow[t]{2}{*}{ LIBOR-OIS Change } & 1.054 & 1.807 & 3.085 & 1.298 \\
\hline & $(3.03)^{* * *}$ & $(2.43)^{* *}$ & $(2.63)^{* * *}$ & (1.37) \\
\hline \multirow[t]{2}{*}{ CNAV * LIBOR-OIS Change } & -2.261 & -2.119 & -5.919 & 2.022 \\
\hline & $(1.88)^{*}$ & $(0.64)$ & $(1.86)^{*}$ & $(0.62)$ \\
\hline \multirow[t]{2}{*}{ Sponsor CDS Data } & 0.708 & & & \\
\hline & $(3.94)^{* * *}$ & & & \\
\hline CNAV * Sponsor CDS Data & $\begin{array}{l}-0.213 \\
(0.23)\end{array}$ & & & \\
\hline \multirow[t]{2}{*}{ Sponsor CDS Change } & -0.400 & -0.481 & -0.348 & -1.406 \\
\hline & $(2.89)^{* * *}$ & $(2.76)^{* * *}$ & $(2.11)^{* *}$ & $(4.25)^{* * *}$ \\
\hline \multirow[t]{2}{*}{ CNAV * Sponsor CDS Change } & 0.134 & 0.132 & 0.049 & 1.831 \\
\hline & $(0.66)$ & $(0.52)$ & $(0.19)$ & $(4.44)^{* * *}$ \\
\hline \multirow[t]{2}{*}{ Constant } & -8.787 & & & \\
\hline & $(8.55)^{* * *}$ & & & \\
\hline Observations & 389,879 & 118,390 & 48,630 & 66,716 \\
\hline \multirow[t]{2}{*}{ Number of funds } & 471 & 154 & 57 & 91 \\
\hline & $\mathrm{RE}$ & FE & FE & FE \\
\hline
\end{tabular}


Table 5

Panel logit regressions describing outflow behaviour and sponsor reputation.

The dependent variable in these panel logit regressions is a dummy variable that is equal to one whenever a fund sustains outflows of $1 \%$ of fund assets or larger for three consecutive trading days. This regression includes a dummy variable, Sponsor CDS Data, that takes the value of 1 if the fund sponsor has an available CDS price reported by Markit. Fund Business represents the proportion of the fund sponsor's mutual fund assets under management that are not in money market mutual funds as at August 2008. Absolute value of $\mathrm{z}$ statistics are in parentheses. * indicates statistical significance at the $10 \%$ threshold; $* *$ indicates statistical significance at the $5 \%$ threshold; and $* * *$ indicates statistical significance at the $1 \%$ threshold.

\begin{tabular}{|c|c|c|c|c|}
\hline \multirow[b]{2}{*}{ CNAV } & \multicolumn{2}{|c|}{ US Dollar } & \multicolumn{2}{|c|}{ Euro } \\
\hline & $\begin{array}{c}1.483 \\
(3.06) * * *\end{array}$ & $\begin{array}{c}1.503 \\
(3.16) * *\end{array}$ & $\begin{array}{l}0.797 \\
(1.10)\end{array}$ & $\begin{array}{l}0.756 \\
(106)\end{array}$ \\
\hline \multirow[t]{2}{*}{ Institutional } & 1.384 & 1.521 & 1.029 & 1.047 \\
\hline & $(5.96)^{* * *}$ & $(6.65)^{* * *}$ & $(3.79)^{* * *}$ & $(3.78)^{* * *}$ \\
\hline \multirow[t]{2}{*}{ Ln (Fund Size) } & -0.083 & -0.040 & 0.073 & 0.067 \\
\hline & $(2.10)^{* *}$ & $(1.06)$ & $(2.59)^{* * *}$ & $(2.38)^{* *}$ \\
\hline \multirow[t]{2}{*}{ Crisis } & 0.762 & 0.669 & -0.271 & -0.278 \\
\hline & $(2.61)^{* * *}$ & $(2.33)^{* *}$ & $(1.62)$ & $(1.66)^{*}$ \\
\hline \multirow[t]{2}{*}{ CNAV $*$ Crisis } & 0.846 & 0.902 & 1.961 & 1.976 \\
\hline & $(2.76)^{* * *}$ & $(2.98) * * *$ & $(6.02)^{* * *}$ & $(6.07)^{* * *}$ \\
\hline \multirow[t]{2}{*}{ Guarantee Date } & 1.184 & 1.205 & 0.498 & 0.504 \\
\hline & $(7.15)^{* * *}$ & $(7.49) * * *$ & $(5.46)^{* * *}$ & $(5.56)^{* * *}$ \\
\hline \multirow[t]{2}{*}{ CNAV * Guarantee Date } & -0.091 & -0.105 & 0.232 & 0.217 \\
\hline & $(0.49)$ & $(0.58)$ & $(1.10)$ & $(1.03)$ \\
\hline \multirow[t]{2}{*}{ US * CNAV * Guarantee Date } & -0.496 & -0.537 & & \\
\hline & $(3.56)^{* * *}$ & $(3.90) * * *$ & & \\
\hline \multirow[t]{2}{*}{ Post Guarantee } & 0.346 & 0.384 & 1.412 & 1.380 \\
\hline & $(1.71)^{*}$ & $(1.95)^{*}$ & $(10.21)^{* * *}$ & $(10.05)^{* * *}$ \\
\hline \multirow{2}{*}{ CNAV * Post Guarantee } & 0.282 & 0.221 & 0.126 & 0.130 \\
\hline & $(1.66)^{*}$ & $(1.34)$ & $(0.69)$ & $(0.71)$ \\
\hline \multirow[t]{2}{*}{ LIBOR-OIS Change } & 0.935 & 0.857 & 1.065 & 1.015 \\
\hline & $(2.13)^{* *}$ & $(2.02)^{* *}$ & $(3.04)^{* * *}$ & $(2.91)^{* * *}$ \\
\hline \multirow[t]{2}{*}{ CNAV * LIBOR-OIS Change } & -0.426 & -0.278 & -2.586 & -2.535 \\
\hline & $(0.89)$ & $(0.60)$ & $(2.17)^{* *}$ & $(2.12)^{* *}$ \\
\hline \multirow[t]{2}{*}{ Fund Business } & -1.561 & & -0.526 & \\
\hline & $(1.55)$ & & $(1.23)$ & \\
\hline \multirow[t]{2}{*}{ CNAV * Fund Business } & -0.174 & & -0.598 & \\
\hline & $(0.16)$ & & $(0.41)$ & \\
\hline \multirow[t]{2}{*}{ Non-Fund Business } & & -0.989 & & 0.509 \\
\hline & & $(1.99)^{* *}$ & & $(1.74)^{*}$ \\
\hline \multirow[t]{2}{*}{ CNAV * Non-fund Business } & & 0.968 & & 0.591 \\
\hline & & $(1.74)^{*}$ & & $(0.56)$ \\
\hline \multirow[t]{2}{*}{ Constant } & -6.522 & -7.468 & -9.191 & -8.632 \\
\hline & $(6.97)^{* * *}$ & $(8.42)^{* * *}$ & $(7.89)^{* * *}$ & $(8.06)^{* * *}$ \\
\hline Country dummy variables & YES & YES & YES & YES \\
\hline Year dummy variables & YES & YES & YES & YES \\
\hline Observations & 212,699 & 222,785 & 379,703 & 385,525 \\
\hline Number of funds & 277 & 290 & 455 & 466 \\
\hline
\end{tabular}


Table 6

Cox survival models describing fund liquidations

The dependent variable in these regressions is a dummy variable that is equal to one if the fund was merged or liquidated. Standard errors are clustered at the fund level. Absolute value of $\mathrm{z}$ statistics are in parentheses. * indicates statistical significance at the 10\% threshold; ** indicates statistical significance at the 5\% threshold; and $* * *$ indicates statistical significance at the $1 \%$ threshold.

\begin{tabular}{|c|c|c|c|c|}
\hline \multirow[b]{2}{*}{ Outflows } & \multicolumn{2}{|c|}{ US Dollar } & \multicolumn{2}{|c|}{ Euro } \\
\hline & $\begin{array}{c}35.628 \\
(4.26)^{* * *}\end{array}$ & $\begin{array}{c}43.124 \\
(4.94)^{* * *}\end{array}$ & $\begin{array}{c}18.233 \\
(2.35)^{* *}\end{array}$ & $\begin{array}{c}20.036 \\
(2.80)^{* * *}\end{array}$ \\
\hline CNAV & $\begin{array}{c}1.613 \\
(1.94)^{*}\end{array}$ & $\begin{array}{c}1.575 \\
(1.84)^{*}\end{array}$ & $\begin{array}{c}-1.104 \\
(0.39)\end{array}$ & $\begin{array}{l}2.994 \\
(1.29)\end{array}$ \\
\hline CNAV * Outflows & $\begin{array}{l}-24.918 \\
(1.84)^{*}\end{array}$ & $\begin{array}{c}-32.287 \\
(2.62)^{* * *}\end{array}$ & $\begin{array}{c}-15.759 \\
(1.26)\end{array}$ & $\begin{array}{l}-1826.419 \\
(2.67)^{* * *}\end{array}$ \\
\hline Institutional & $\begin{array}{r}-0.091 \\
(0.18)\end{array}$ & $\begin{array}{c}-0.089 \\
(0.15)\end{array}$ & $\begin{array}{l}0.301 \\
(0.64)\end{array}$ & $\begin{array}{c}-0.300 \\
(0.55)\end{array}$ \\
\hline Ln (Fund Size) & $\begin{array}{c}-0.926 \\
(3.85)^{* * *}\end{array}$ & $\begin{array}{c}-0.935 \\
(4.04)^{* * *}\end{array}$ & $\begin{array}{c}-0.601 \\
(4.12)^{* * *}\end{array}$ & $\begin{array}{c}-0.584 \\
(4.18)^{* * *}\end{array}$ \\
\hline Sponsor CDS Data & & & & \\
\hline CNAV * Sponsor CDS Data & & & & \\
\hline Fund Business & $\begin{array}{c}-3.636 \\
(2.32)^{* *}\end{array}$ & & $\begin{array}{c}1.861 \\
(2.77)^{* * *}\end{array}$ & \\
\hline CNAV $*$ Fund Business & $\begin{array}{c}3.555 \\
(1.71)^{*}\end{array}$ & & $\begin{array}{l}7.023 \\
(1.28)\end{array}$ & \\
\hline Non-Fund Business & & $\begin{array}{l}0.823 \\
(1.16)\end{array}$ & & $\begin{array}{l}0.512 \\
(1.09)\end{array}$ \\
\hline CNAV * Non-Fund Business & & $\begin{array}{l}-0.248 \\
(0.21)\end{array}$ & & $\begin{array}{l}-4.916 \\
(1.58)\end{array}$ \\
\hline Country dummy variables & YES & YES & YES & YES \\
\hline Observations & 217,798 & 228,288 & 379,705 & 385,525 \\
\hline Subjects & 277 & 290 & 455 & 466 \\
\hline Failures & 19 & 20 & 54 & 60 \\
\hline
\end{tabular}


Table 7

Convexity in the flow-performance relationship.

The dependent variable in these fixed effects panel regressions is a fund's daily net inflows (scaled by assets). This regression allows for first order autocorrelation in the disturbance term. Absolute value of z statistics are in parentheses. $*$ indicates statistical significance at the $10 \%$ threshold; $* *$ indicates statistical significance at the $5 \%$ threshold; and $* * *$ indicates statistical significance at the $1 \%$ threshold.

\begin{tabular}{|c|c|c|c|}
\hline \multicolumn{4}{|l|}{ Panel A: U.S. Dollar funds } \\
\hline & $\underline{\text { All }}$ & Low Return & High Return \\
\hline \multirow[t]{2}{*}{ Flow (Lagged) } & $-\overline{0.237}$ & -0.223 & -0.242 \\
\hline & $(48.34) * * *$ & $(28.81)^{* * *}$ & $(34.26)^{* * *}$ \\
\hline \multirow[t]{2}{*}{ CNAV * Flow (Lagged) } & -0.037 & -0.062 & -0.024 \\
\hline & $(6.84)^{* * *}$ & $(7.45)^{* * *}$ & $(3.08)^{* * *}$ \\
\hline \multirow[t]{2}{*}{ LIBOR-OIS Change } & 0.000 & 0.002 & -0.003 \\
\hline & $(0.31)$ & $(2.18)^{* *}$ & $(2.02)^{* *}$ \\
\hline \multirow[t]{2}{*}{ CNAV * LIBOR-OIS Change } & -0.000 & 0.001 & -0.001 \\
\hline & $(0.49)$ & $(0.81)$ & $(0.33)$ \\
\hline \multirow[t]{2}{*}{ Lagged Return $^{+}$} & 0.003 & -0.001 & 0.007 \\
\hline & $(0.93)$ & $(0.13)$ & $(0.97)$ \\
\hline \multirow[t]{2}{*}{$\mathrm{CNAV}^{*}$ Lagged Return $^{+}$} & 0.003 & 0.011 & -0.004 \\
\hline & $(0.55)$ & $(1.24)$ & $(0.45)$ \\
\hline \multirow[t]{2}{*}{ Lagged Return ${ }^{-}$} & 0.012 & 0.001 & 0.003 \\
\hline & $(2.52)^{* *}$ & $(0.19)$ & $(0.28)$ \\
\hline \multirow[t]{2}{*}{ CNAV * Lagged Return ${ }^{-}$} & -0.000 & -0.027 & 0.054 \\
\hline & $(0.02)$ & $(1.81)^{*}$ & $(2.69)^{* * *}$ \\
\hline \multirow[t]{2}{*}{ Average flows } & 0.937 & 0.802 & 1.091 \\
\hline & $(61.82)^{* * *}$ & $(39.93)^{* * *}$ & $(44.81)^{* * *}$ \\
\hline \multirow[t]{2}{*}{ Return Volatility } & 0.000 & 0.012 & -0.007 \\
\hline & $(0.04)$ & $(1.19)$ & $(0.50)$ \\
\hline \multirow[t]{2}{*}{ Constant } & 0.000 & 0.000 & -0.000 \\
\hline & $(0.15)$ & $(0.70)$ & (1.19) \\
\hline Observations & 217,328 & 100,364 & 102,488 \\
\hline Number of funds & 287 & 125 & 127 \\
\hline \multicolumn{4}{|l|}{ Panel B: Euro funds } \\
\hline & All & Low Return & High Return \\
\hline \multirow[t]{2}{*}{ Flow (Lagged) } & $-\overline{0.287}$ & -0.279 & -0.291 \\
\hline & $(184.45) * * *$ & $(124.97) * * *$ & $(128.49)^{* * *}$ \\
\hline \multirow[t]{2}{*}{ CNAV * Flow (Lagged) } & -0.013 & -0.031 & 0.012 \\
\hline & $(2.56)^{* *}$ & $(5.16)^{* * *}$ & $(1.25)$ \\
\hline \multirow[t]{2}{*}{ LIBOR-OIS Change } & 0.000 & 0.001 & -0.000 \\
\hline & $(0.04)$ & $(0.96)$ & $(0.48)$ \\
\hline \multirow[t]{2}{*}{ CNAV * LIBOR-OIS Change } & 0.003 & 0.004 & -0.003 \\
\hline & $(0.98)$ & $(1.60)$ & $(0.61)$ \\
\hline \multirow[t]{2}{*}{ Lagged Return $^{+}$} & 0.005 & -0.001 & 0.011 \\
\hline & $(3.23)^{* * *}$ & $(0.53)$ & $(4.39)^{* * *}$ \\
\hline \multirow[t]{2}{*}{$\mathrm{CNAV}^{*}$ Lagged Return $^{+}$} & -0.007 & -0.001 & -0.030 \\
\hline & $(0.27)$ & $(0.02)$ & $(0.80)$ \\
\hline \multirow[t]{2}{*}{ Lagged Return $^{-}$} & 0.004 & 0.007 & 0.000 \\
\hline & $(2.04)^{* *}$ & $(3.40)^{* * *}$ & $(0.08)$ \\
\hline \multirow[t]{2}{*}{$\mathrm{CNAV}^{*}$ Lagged Return $^{-}$} & 0.025 & -0.018 & 0.135 \\
\hline & $(0.84)$ & $(0.58)$ & $(2.28)^{* *}$ \\
\hline \multirow[t]{2}{*}{ Average flows } & 0.973 & 0.805 & 1.243 \\
\hline & $(91.70)^{* * *}$ & $(68.95)^{* * *}$ & $(63.21)^{* * *}$ \\
\hline \multirow[t]{2}{*}{ Return Volatility } & -0.009 & -0.012 & -0.007 \\
\hline & $(2.59)^{* * *}$ & $(2.94) * * *$ & $(0.95)$ \\
\hline
\end{tabular}




\begin{tabular}{lccc}
\hline Constant & -0.000 & -0.000 & 0.000 \\
& $(2.43)^{* *}$ & $(2.04)^{* *}$ & $(0.45)$ \\
Observations & 405,471 & 212,029 & 183,316 \\
Number of funds & 468 & 217 & 218 \\
\hline
\end{tabular}


Table 8

Panel logit regressions describing inflow behaviour.

The dependent variable in these panel logit regressions is a dummy variable that is equal to one whenever a fund sustains net inflows of $1 \%$ of fund assets or larger for three consecutive trading days. Absolute value of $z$ statistics are in parentheses. $*$ indicates statistical significance at the $10 \%$ threshold; ** indicates statistical significance at the $5 \%$ threshold; and $* * *$ indicates statistical significance at the $1 \%$ threshold.

\begin{tabular}{|c|c|c|c|c|c|c|}
\hline & \multicolumn{3}{|c|}{ US Dollar } & \multicolumn{3}{|c|}{ Euro } \\
\hline & $\underline{\text { All }}$ & $\underline{\underline{\text { Low }}} \underline{\underline{\text { Return }}}$ & $\underline{\text { High }}$ & $\underline{\text { All }}$ & $\underline{\underline{\text { Low }}} \underline{\text { Return }}$ & $\underline{\text { High }}$ \\
\hline \multirow[t]{2}{*}{ CNAV } & 0.984 & 3.156 & $\overline{-0.234}$ & 1.142 & 1.653 & 1.842 \\
\hline & $(2.36)^{* *}$ & $(4.22)^{* * *}$ & $(0.38)$ & $(1.49)$ & $(1.12)$ & $(1.71)^{*}$ \\
\hline \multirow[t]{2}{*}{ Institutional } & 1.004 & 0.762 & 1.059 & 1.276 & 1.206 & 0.942 \\
\hline & $(4.98)^{* * *}$ & $(2.32)^{* *}$ & $(3.89)^{* * *}$ & $(4.40)^{* * *}$ & $(1.55)$ & $(3.20)^{* * *}$ \\
\hline \multirow[t]{2}{*}{ Ln (Fund Size) } & 0.279 & 0.270 & 0.277 & 0.038 & 0.023 & -0.020 \\
\hline & $(7.57)^{* * *}$ & $(4.90)^{* * *}$ & $(4.93)^{* * *}$ & $(1.89)^{*}$ & $(0.98)$ & $(0.56)$ \\
\hline \multirow[t]{2}{*}{ Crisis } & 0.817 & 2.275 & -1.108 & 0.020 & 0.648 & -0.934 \\
\hline & $(2.91)^{* * *}$ & $(6.34)^{* * *}$ & $(1.51)$ & $(0.18)$ & $(4.80)^{* * *}$ & $(4.00)^{* * *}$ \\
\hline \multirow[t]{2}{*}{ CNAV * Crisis } & -1.309 & -2.655 & 0.354 & -1.335 & -2.276 & 0.144 \\
\hline & $(4.13)^{* * *}$ & $(6.61)^{* * *}$ & $(0.45)$ & $(1.84)^{*}$ & $(2.23)^{* *}$ & $(0.14)$ \\
\hline \multirow[t]{2}{*}{ Guarantee Date } & 0.089 & -0.432 & 0.016 & 0.455 & 1.095 & -0.440 \\
\hline & $(0.51)$ & $(1.19)$ & $(0.07)$ & $(6.69) * * *$ & $(10.79)^{* * *}$ & $(3.93)^{* * *}$ \\
\hline \multirow[t]{2}{*}{ CNAV * Guarantee } & 0.287 & 0.446 & 0.108 & 0.235 & -0.203 & 0.696 \\
\hline & $(1.44)$ & $(1.06)$ & $(0.43)$ & $(1.47)$ & $(0.99)$ & $(2.64)^{* * *}$ \\
\hline \multirow[t]{2}{*}{ US * CNAV * Guarantee } & 0.029 & -0.022 & 0.409 & & & \\
\hline & $(0.19)$ & $(0.09)$ & $(1.65)^{*}$ & & & \\
\hline \multirow[t]{2}{*}{ Post Guarantee } & 0.367 & 0.831 & -0.024 & -0.026 & 0.018 & -0.711 \\
\hline & $(1.99)^{* *}$ & $(2.50)^{* *}$ & $(0.10)$ & $(0.20)$ & $(0.07)$ & $(4.19)^{* * *}$ \\
\hline \multirow{2}{*}{ CNAV * Post Guarantee } & -0.120 & -1.169 & 0.405 & 0.447 & 0.100 & 0.910 \\
\hline & $(0.87)$ & $(4.92)^{* * *}$ & $(2.19)^{* *}$ & $(3.06)^{* * *}$ & $(0.50)$ & $(4.08)^{* * *}$ \\
\hline \multirow[t]{2}{*}{ LIBOR-OIS $\Delta$} & -0.702 & -0.417 & -0.174 & 1.179 & 2.214 & 0.235 \\
\hline & $(1.41)$ & $(0.45)$ & $(0.26)$ & $(4.40)^{* * *}$ & $(6.16)^{* * *}$ & $(0.53)$ \\
\hline \multirow[t]{2}{*}{ CNAV $*$ LIBOR-OIS $\Delta$} & 1.916 & 3.071 & 0.064 & -3.297 & -4.551 & -1.755 \\
\hline & $(3.60)^{* * *}$ & $(3.17)^{* * *}$ & $(0.09)$ & $(3.26)^{* * *}$ & $(3.71)^{* * *}$ & $(0.95)$ \\
\hline \multirow[t]{2}{*}{ Constant } & -12.934 & -14.227 & -11.731 & -7.504 & -7.011 & -5.846 \\
\hline & $(14.66)^{* * *}$ & $(10.05)^{* * *}$ & $(8.96)^{* * *}$ & $(7.17)^{* * *}$ & $(4.24) * * *$ & $(4.23)^{* * *}$ \\
\hline Country dummy variables & YES & YES & YES & YES & YES & YES \\
\hline Year dummy variables & YES & YES & YES & YES & YES & YES \\
\hline Panel regression type & $\mathrm{RE}$ & $\mathrm{RE}$ & $\mathrm{RE}$ & $\mathrm{RE}$ & $\mathrm{RE}$ & $\mathrm{RE}$ \\
\hline Observations & 227,549 & 100,916 & 104,664 & 389,879 & 204,094 & 169,613 \\
\hline Number of funds & 296 & 125 & 127 & 471 & 217 & 218 \\
\hline
\end{tabular}


Table 9

Robustness tests.

In the non-U.S. domiciled specification, the dependent variable in these panel logit regressions is a dummy variable that is equal to one whenever a fund sustains withdrawals of $1 \%$ of fund assets or larger for three consecutive trading days. This specification excludes funds domiciled in the U.S. For the Narrow Definition specification, a fund is only defined as a constant NAV fund if its share price (i.e., net asset value) does not change during the sample period. For the Daily Run specification, the dependent variable is a dummy variable that is equal to one whenever a fund sustains withdrawals of $10 \%$ of fund assets or larger on a single trading day. Absolute value of $z$ statistics are in parentheses. $*$ indicates statistical significance at the $10 \%$ threshold; $* *$ indicates statistical significance at the $5 \%$ threshold; and $* * *$ indicates statistical significance at the $1 \%$ threshold.

\begin{tabular}{|c|c|c|c|c|c|}
\hline & \multicolumn{3}{|c|}{ US Dollar } & \multicolumn{2}{|c|}{ Euro } \\
\hline & $\frac{\text { Non-U.S. }}{\text { Domiciled }}$ & $\frac{\text { Broad }}{\text { Def'n }}$ & Daily Run & $\frac{\text { Broad }}{\text { Def'n }}$ & Daily Run \\
\hline CNAV & $\begin{array}{c}1.794 \\
(2.82)^{* * *}\end{array}$ & $\begin{array}{c}\overline{1.128} \\
(2.62)^{* * *}\end{array}$ & $\begin{array}{c}1.054 \\
(2.45)^{* *}\end{array}$ & $\begin{array}{c}\overline{0.463} \\
(2.15)^{* *}\end{array}$ & $\begin{array}{c}2.240 \\
(3.81)^{* * *}\end{array}$ \\
\hline Institutional & $\begin{array}{l}0.191 \\
(0.37)\end{array}$ & $\begin{array}{c}1.452 \\
(6.40)^{* * *}\end{array}$ & $\begin{array}{c}1.468 \\
(6.64)^{* * *}\end{array}$ & $\begin{array}{c}0.955 \\
(3.53)^{* * *}\end{array}$ & $\begin{array}{c}0.913 \\
(3.85)^{* * *}\end{array}$ \\
\hline Ln (Fund Size) & $\begin{array}{l}-0.098 \\
(1.32)\end{array}$ & $\begin{array}{l}-0.051 \\
(1.42)\end{array}$ & $\begin{array}{c}-0.448 \\
(12.60)^{* * *}\end{array}$ & $\begin{array}{c}0.044 \\
(1.66)^{*}\end{array}$ & $\begin{array}{c}-0.223 \\
(9.64)^{* * *}\end{array}$ \\
\hline Crisis & $\begin{array}{c}0.663 \\
(2.10)^{* *}\end{array}$ & $\begin{array}{c}0.627 \\
(1.97)^{* *}\end{array}$ & $\begin{array}{l}0.396 \\
(1.15)\end{array}$ & $\begin{array}{c}-0.748 \\
(2.68) * * *\end{array}$ & $\begin{array}{l}0.069 \\
(0.39)\end{array}$ \\
\hline CNAV $*$ Crisis & $\begin{array}{c}1.375 \\
(3.41)^{* * *}\end{array}$ & $\begin{array}{c}0.993 \\
(2.96)^{* * *}\end{array}$ & $\begin{array}{c}1.124 \\
(2.97)^{* * *}\end{array}$ & $\begin{array}{c}1.552 \\
(4.83)^{* * *}\end{array}$ & $\begin{array}{l}0.358 \\
(0.81)\end{array}$ \\
\hline Guarantee Date & $\begin{array}{c}0.987 \\
(6.42)^{* * *}\end{array}$ & $\begin{array}{c}0.837 \\
(5.58)^{* * *}\end{array}$ & $\begin{array}{l}-0.027 \\
(0.16)\end{array}$ & $\begin{array}{l}0.109 \\
(1.30)\end{array}$ & $\begin{array}{l}-0.046 \\
(0.64)\end{array}$ \\
\hline CNAV $*$ Guarantee & $\begin{array}{l}-0.354 \\
(1.56)\end{array}$ & $\begin{array}{r}-0.123 \\
(0.68)\end{array}$ & $\begin{array}{c}0.627 \\
(2.65)^{* * *}\end{array}$ & $\begin{array}{c}-0.292 \\
(2.44)^{* *}\end{array}$ & $\begin{array}{l}-0.034 \\
(0.15)\end{array}$ \\
\hline US * CNAV * Guarantee & & $\begin{array}{c}-0.522 \\
(4.07)^{* * *}\end{array}$ & $\begin{array}{c}-0.749 \\
(3.92)^{* * *}\end{array}$ & & \\
\hline Post Guarantee & $\begin{array}{l}-0.011 \\
(0.07)\end{array}$ & $\begin{array}{l}-0.092 \\
(0.58)\end{array}$ & $\begin{array}{l}-0.289 \\
(1.95)^{*}\end{array}$ & $\begin{array}{c}0.226 \\
(3.25)^{* * *}\end{array}$ & $\begin{array}{l}-0.090 \\
(1.55)\end{array}$ \\
\hline CNAV * Post Guarantee & $\begin{array}{c}0.396 \\
(1.66)^{*}\end{array}$ & $\begin{array}{l}0.238 \\
(1.37)\end{array}$ & $\begin{array}{l}0.118 \\
(0.65)\end{array}$ & $\begin{array}{l}0.108 \\
(1.14)\end{array}$ & $\begin{array}{l}-0.031 \\
(0.16)\end{array}$ \\
\hline LIBOR-OIS $\Delta$ & $\begin{array}{c}1.308 \\
(2.74)^{* * *}\end{array}$ & $\begin{array}{c}1.285 \\
(2.61)^{* * *}\end{array}$ & $\begin{array}{c}2.405 \\
(4.40)^{* * *}\end{array}$ & $\begin{array}{c}2.280 \\
(4.81)^{* * *}\end{array}$ & $\begin{array}{c}0.979 \\
(2.15)^{* *}\end{array}$ \\
\hline CNAV $*$ LIBOR-OIS $\Delta$ & $\begin{array}{l}-0.776 \\
(1.10)\end{array}$ & $\begin{array}{l}-0.493 \\
(0.93)\end{array}$ & $\begin{array}{c}-1.517 \\
(2.41)^{* *}\end{array}$ & $\begin{array}{c}-1.807 \\
(2.50)^{* *}\end{array}$ & $\begin{array}{l}1.149 \\
(0.92)\end{array}$ \\
\hline Constant & $\begin{array}{l}-3.302 \\
(1.94)^{*}\end{array}$ & $\begin{array}{c}-6.393 \\
(7.70)^{* * *}\end{array}$ & $\begin{array}{l}1.234 \\
(1.55)\end{array}$ & $\begin{array}{c}-7.458 \\
(7.28)^{* * *}\end{array}$ & $\begin{array}{c}-4.211 \\
(3.55)^{* * *}\end{array}$ \\
\hline Country dummy variables & YES & YES & YES & YES & YES \\
\hline Year dummy variables & $\begin{array}{l}\text { YES } \\
\text { RE }\end{array}$ & $\begin{array}{l}\text { YES } \\
\text { RE }\end{array}$ & $\begin{array}{l}\text { YES } \\
\text { RE }\end{array}$ & $\begin{array}{l}\text { YES } \\
\text { RE }\end{array}$ & $\begin{array}{l}\text { YES } \\
\text { RE }\end{array}$ \\
\hline Observations & 73,818 & 227,549 & 245,504 & 389,879 & 478,701 \\
\hline Number of funds & 92 & 296 & 296 & 471 & 471 \\
\hline
\end{tabular}


Figure 1a. Withdrawals for U.S. dollar money market mutual funds.

This figure displays withdrawal behaviour for both constant net asset value (CNAV) and variable net asset value (VNAV) non-government money market mutual funds in both the United States and Europe. A money market mutual fund is defined as a CNAV fund if it maintains a fixed share price of $\$ 1$ or $\$ 10$, or if it has never experienced a decline in its net asset value. Otherwise, the fund is considered to be a VNAV fund. A fund is considered to experience consecutive withdrawals if it sustains withdrawals of $1 \%$ or larger for three consecutive trading days.

\section{USD MMF Withdrawals}

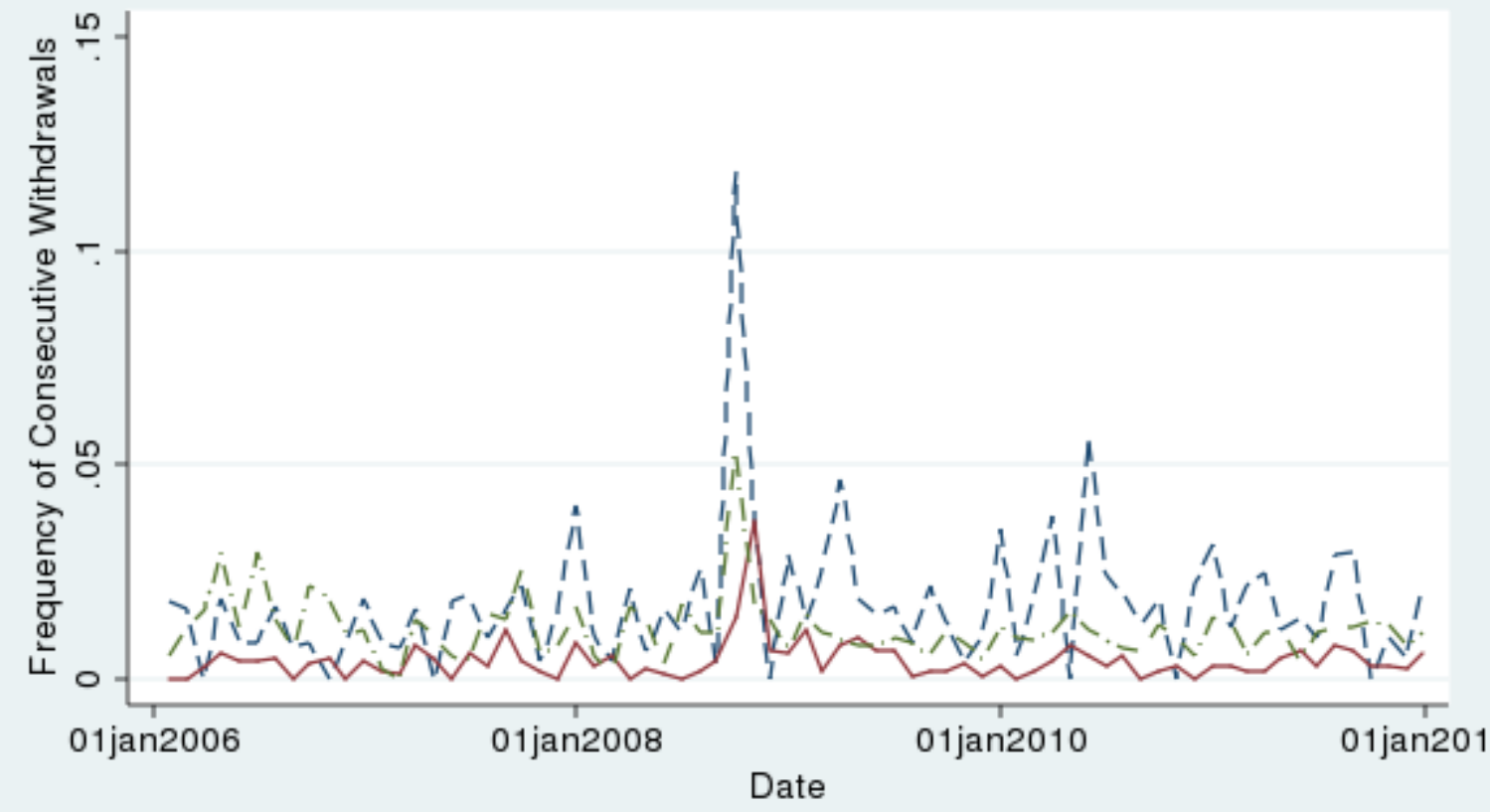

$$
\begin{aligned}
& ----- \text { Non-US CNAV } \\
& --\cdot-- \text { US CNAV }
\end{aligned}
$$


Figure 1b. Withdrawals for Euro money market mutual funds.

This figure displays withdrawal behaviour for both constant net asset value (CNAV) and variable net asset value (VNAV) non-government money market mutual funds in Europe. A money market mutual fund is defined as a CNAV fund if it maintains a fixed share price of $\$ 1$ or $\$ 10$, or if it has never experienced a decline in its net asset value. Otherwise, the fund is considered to be a VNAV fund. A fund is considered to experience consecutive withdrawals if it sustains withdrawals of $1 \%$ or larger for three consecutive trading days.

\section{Euro MMF Withdrawals}

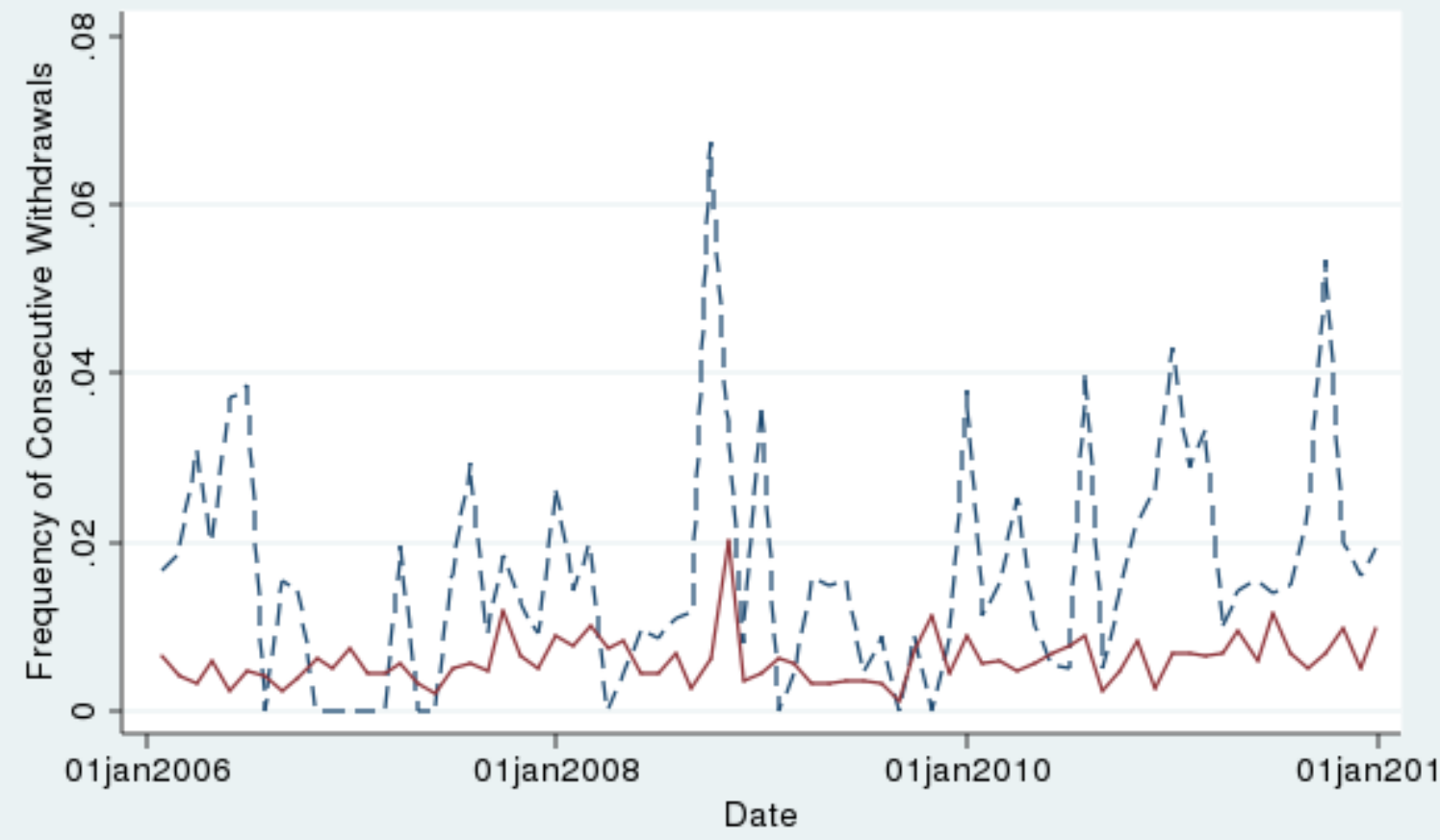

$$
\text { ----- European CNAV — European VNAV }
$$

